UNIVERSIDADE DE SÃO PAULO

FFCLRP - DEPARTAMENTO DE PSICOLOGIA E EDUCAÇÃO

PROGRAMA DE PÓS-GRADUAÇÃO EM PSICOBIOLOGIA

\title{
Expressão da Proteína Fos em Cérebro de Ratos Expostos ao Labirinto em Cruz Elevado na Presença e Ausência de Iluminação
}

Javier Leonardo Rico Rodríguez

Dissertação apresentada à Faculdade de

Filosofia, Ciências e Letras de Ribeirão Preto da USP, como parte das exigências para obtenção do título de Mestre em Ciências, área de Psicobiologia.

Ribeirão Preto - SP

2006 
UNIVERSIDADE DE SÃO PAULO

FFCLRP - DEPARTAMENTO DE PSICOLOGIA E EDUCAÇÃO

PROGRAMA DE PÓS-GRADUAÇÃO EM PSICOBIOLOGIA

\title{
Expressão da Proteína Fos em Cérebro de Ratos Expostos ao Labirinto em Cruz Elevado na Presença e Ausência de iluminação
}

\begin{abstract}
Dissertação apresentada à Faculdade de Filosofia, Ciências e Letras de Ribeirão Preto da USP, como parte das exigências para obtenção do título de Mestre em Ciências, área de Psicobiologia.
\end{abstract}

Javier Leonardo Rico Rodríguez

Orientador: Prof. Silvio Morato

Ribeirão Preto - SP

2006 


\section{FICHA CATALOGRÁFICA}

Rico, Javier Leonardo Rodríguez

Expressão da Proteína Fos em Cérebro de Ratos Expostos ao Labirinto em Cruz Elevado na ausência e presença de iluminação. Ribeirão Preto, 2006.

46 p. ; il. ; $30 \mathrm{~cm}$.

Dissertação de Mestrado, apresentada à Faculdade de Filosofia, Ciências e Letras de Ribeirão Preto/USP - Área de concentração: Psicobiologia.

Orientador: Morato, Silvio.

1. Labirinto em cruz elevado. 2. Proteína Fos. 3. Ansiedade

4. lluminação. 5. Comportamento exploratório. 
Aos meus pais, meus grandes mestres.

Ao Leonardo, meu Filho, por lembrar-me que estamos aqui para Brincar.

À Claudia, por ajudar-me a permanecer no presente. 
Agradecimentos.

Agradeço ao CNPq pela ajuda científica e apoio financeiro

Agradeço ao professor Silvio Morato pela confiança e apoio depositado no meu trabalho e pela contribuição na minha formação.

Faço um agradecimento especial à Karina Borelli pela contribuição na parte final da coleta dos dados. O seu apoio permitiu o fortalecimentos dos resultados apresentados. Além do seu profissionalismo e dedicação na ajuda oferecida, agradeço pela qualidade humana. Muito obrigado Karina.

Agradeço ao professor Marcus Brandão por facilitar-me a utilização dos equipamentos do laboratório de neuroquímica e pela contribuição na coleta de dados.

Aos professores membros da banca examinadora pela leitura da dissertação.

A todos os que de alguma forma contribuíram na realização deste trabalho, aos funcionários do programa pela ajuda. À Renata, Inês, Denise e Sônia.

Ao Fernando pela amizade.

Agradeço à Milena por indicar-me o caminho e algumas dicas para percorrê-lo. A todos os amigos, Aninha, Ari, Célio, Diogo, Imaculada, Paulinho, Túlio e à Selma.

À minha família no Brasil, Leonardito, Laurita, Claudia, Zaida, Julian, Lina, Milena, Fredy, Guillermo, Omar, Umberto, Jorge e Orfa.

À minha família na Colômbia pelo apoio e a força constante.

E ao pescador da balsa amarela por não sucumbir nas águas de Bogotá e por ter a coragem de mergulhar profundo nesse submarino. 


\section{Conteúdo}

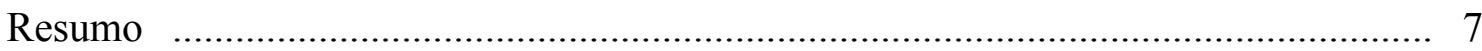

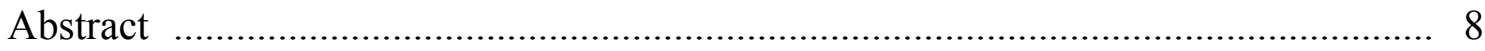

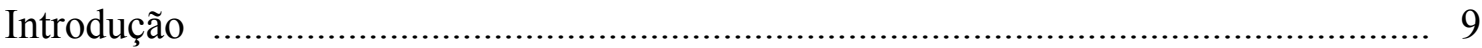

Efeito da luminosidade sobre o comportamento de animais noturnos …........................... 9

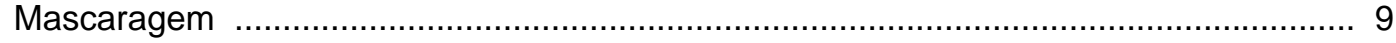

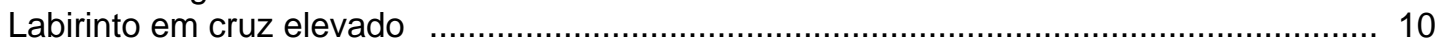

Efeito da luminosidade sobre o comportamento de ratos testados no

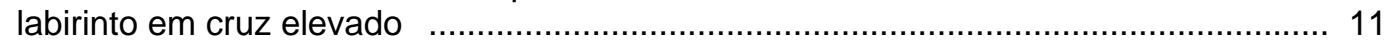

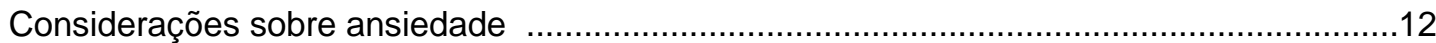

Proteína Fos como marcador funcional …............................................................... 13

Expressão de Fos em ratos testados no labirinto em cruz elevado ............................... 14

Expressão de Fos e luminosidade ....................................................................... 15

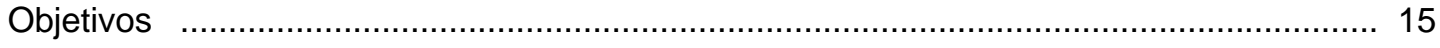

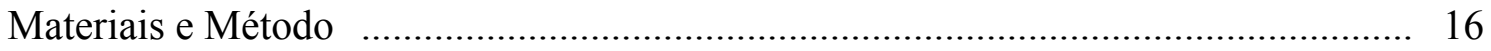

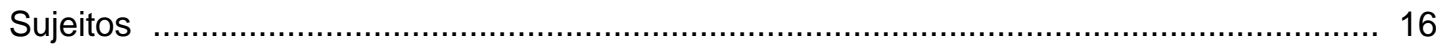

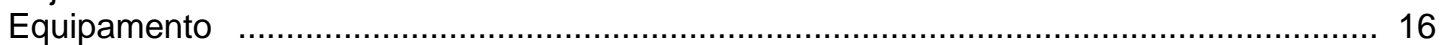

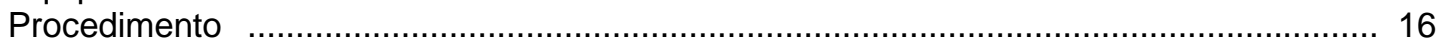

Teste no labirinto em cruz elevado e condições de controle ........................................ 17

Perfusão e marcação imunoistoquímica de Fos ……............................................... 17

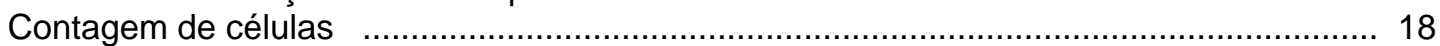

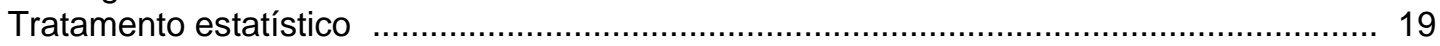

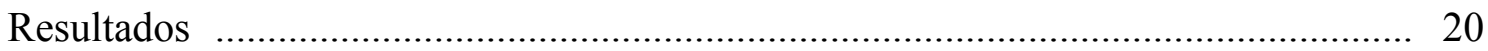

Comportamento no labirinto em cruz elevado ……................................................ 20

Expressão da proteína Fos ……………………................................................. 22

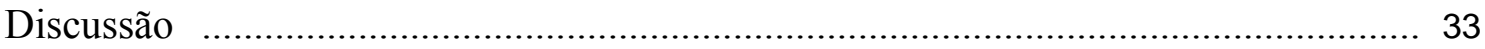

Comportamento no labirinto em cruz elevado ………............................................... 33

Expressão da proteína Fos ………………....................................................... 34

Exposição ao labirinto em cruz elevado: comparação com os estudos prévios ........... 34

Exposição ao ambiente familiar e novo ……….......................................................... 36

Exposição ao ambiente iluminado e escuro ...................................................................3

Exposição ao labirinto em cruz elevado: interação entre iluminação e novidade ............38

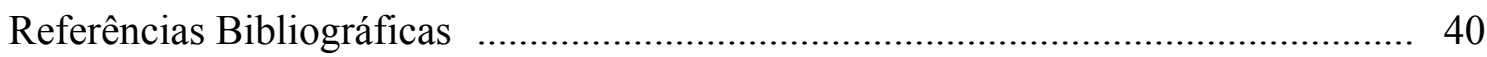

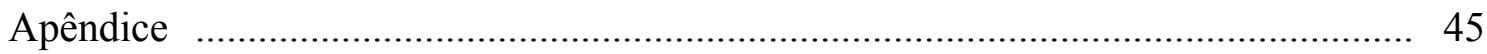




\section{Resumo}

O labirinto em cruz elevado é um teste comportamental sensível à iluminação ambiental. Na ausência de luz, ratos testados neste modelo exibem aumento da exploração dos braços abertos, quando comparados com animais testados em ambientes iluminados. No presente trabalho investigou-se a expressão da proteína Fos em cérebro de ratos expostos ao labirinto em cruz elevado na presença e ausência de iluminação. Duas horas depois do teste no labirinto em cruz elevado, ratos foram perfundidos com paraformaldeído juntamente com outros que somente permaneceram em uma gaiola enquanto os primeiros eram testados no labirinto. Para cada par (labirinto e gaiola) manteve-se a mesma condição de iluminação: claro ou escuro. Ainda, ratos de um terceiro grupo que permanecia no biotério eram perfundidos juntamente com cada dupla. Os cérebros foram retirados e preparados para inicio do procedimento imunoistoquímico da marcação da proteína Fos e posterior contagem de células marcadas. De um modo geral, animais expostos ao labirinto em cruz elevado sem iluminação, exibiram aumento na porcentagem de entradas e tempo de permanência nos braços abertos, assim como aumento da expressão de Fos em diferentes regiões do cérebro. A comparação entre os grupos sugere que a lâmina intergeniculada se relaciona provavelmente com a detecção de iluminação. A exploração de ambientes novos ou familiares envolve a participação do córtex cingulado e do locus coeruleus. Animais testados no labirinto em cruz elevado no escuro exibiram aumentos significativos na expressão de Fos nos núcleos da amígdala lateral, basolateral e medial, núcleos do hipotálamo lateral anterior e dorsomedial, quando comparados com os animais testados no mesmo modelo na presença de luz e com os que somente permaneceram na gaiola no escuro. Além disso, na ausência de luz, correlações significativas entre medidas comportamentais no labirinto em cruz elevado e número de neurônios marcados por Fos mostraram uma relação entre o aumento da exploração dos braços abertos e ativação de neurônios pertencentes à maioria dos núcleos descritos. Os resultados sugerem que a detecção de luminosidade em ambientes novos inibe a ativação neuronal e comportamental inicial. Esse processo induziria uma diminuição do número de neurônios ativos e comportamentos relacionados com ansiedade. A ausência de luz, pelo contrario, manteria a ativação inicial gerada pela novidade e envolveria comportamentos de exploração subjacentes ao aumento da expressão de Fos sobretudo no complexo amigdalóide e córtex piriforme. 


\section{Abstract}

The elevated plus-maze is a behavioral test sensitive to environmental illumination. In the absence of light, rats tested in with this model exhibit increases in the exploration of the open arms, when compared to animals tested in illuminated environments. The present work investigated Fos protein expression in the brain of rats exposed to the elevated plus-maze in the presence and absence of illumination. Two hours after the test in the plus-maze, the rats were perfused with paraformaldehyde together with others that just remained in a cage while the first were tested in the maze. For each pair (maze and cage) the same illumination condition was maintained: light or dark. Also, rats from a third group that only remained in the vivarium were perfused together with each pair. The brains were removed and prepared for the procedure of immunohistochemical staining for Fos followed by cell counting. In general, rats exposed to the elevated plus-maze in the dark exhibited increases in the percentage of entries and time spent in the open arms, as well as increases in Fos expression in different brain areas. Comparisons among groups suggests that intergeniculate leaflet is probably related to illumination detection. The exploration of novel of familiar environments involves the cingulate cortex and the locus coeruleus. Rats tested inn the elevated plus-maze in the dark exhibited significant increases in Fos expression in the lateral, basolateral, medial and central amygdala nuclei, lateral anterior and dorsomedial hypothalamic nuclei when compared to rats tested in this model under illumination and rats that remained in the cage in the dark. Besides, in the dark, significant correlations between behavioral measurements in the maze and amount of Fos-stained cells indicates a relationship between open arm exploration and neuron activation in most of the studied nuclei. The results suggest that light detection in novel environments inhibits the initial neuronal and behavioral activation. This process induces a decrease in the number of active neurons and behaviors related to anxiety. The absence of light, on the other hand, keeps the initial activation generated by novelty and involves the exploratory behaviors subserved by the increases in the expression of Fos protein, mainly in the amygdaloid complex and piriform cortex. 


\section{Introdução}

\section{Efeito da luminosidade sobre o comportamento de animais noturnos}

Um fator importante na evolução dos mamíferos foi a capacidade de permanecerem ativos durante a noite. Esse padrão de adaptação, a transição da atividade diurna à noturna, permitiu-lhes sua rápida expansão dominando assim um nicho até então de pouca concorrência (Crompton e cols., 1978). No entanto, a atividade diurna emergiu novamente em diversas linhagens que evoluíram de forma independente. Tanto para as espécies diurnas como para as noturnas, a luz modula diversos repertórios comportamentais com valores evolutivos específicos. Mamíferos tão diferentes como morcegos, alguns carnívoros, e a maioria dos roedores, incluindo o gênero Rattus, poderiam exibir comportamentos e processos neurais mais semelhantes entre si, do que as espécies diurnas (Smale e cols., 2003). A diferenciação do funcionamento do cérebro na ausência ou presença de luz constitui uma fonte relevante de investigação.

\section{Mascaragem}

Observa-se, em animais noturnos, alterações comportamentais e fisiológicas instantâneas produzidas pela luz. Nessas espécies, a presença de luz no ciclo de noite, suprime a atividade locomotora usualmente observada nesse horário. Isto é conhecido como mascaragem (masking) porque a luz oculta a expressão normal de atividade (Aschoff, 1960; Mrosovsky, 1999). Embora a inibição da locomoção pela luminosidade, ou mascaragem negativa, evidencie-se com maior freqüência em condições de laboratório, há alguns exemplos que ocorrem no ambiente natural nos quais a luminosidade produz efeitos direitos nos repertórios comportamentais. Um caso interessante é o do macaco-coruja (Aotus lemurinus griseimembra), que exibe um padrão de atividade dependente do ciclo lunar (Erkert, 1974). Este macaco noturno exibe uma maior atividade na faixa de luminosidade entre 0,1 e 0,5 lux, mas a mudança da intensidade de luz, produzida pelo brilho da lua cheia, inibe seu comportamento motor. (Ekert, 1974; Erkert e Gröber, 1986). O rato-canguru constitui mais um exemplo da inibição da atividade pela luminosidade da lua (Daly e cols. 2000). Segundo os autores, a esquiva da luz da lua parece reduzir o risco de predação.

Já em ambientes controlados, muitos trabalhos investigam os efeitos da presença ou ausência de luminosidade no comportamento. Nos estudos de mascaragem, utilizamse rodas de atividades para o registro da atividade locomotora. Animais expostos a altas intensidades de luz respondem com menor número de revoluções nas rodas, ou seja, 
menor atividade motora (mascaragem negativa). Por sua vez, estímulos luminosos tênues aumentam a locomoção, resultando em mascaragem positiva (Mrosovsky, 1999a; Redlin e Mrosvsky, 1999).

A mascaragem produzida pela luz é uma função básica do sistema visual, mas os substratos neurais subjacentes são pouco entendidos (Morin e Allen, 2005). No nível da retina, os fotorreceptores clássicos, cones e bastonetes, e o fotorreceptor melanopsina, contribuem para a ocorrência da mascaragem positiva e negativa (Mrosovsky e cols., 1999b; Hattar e cols., 2003; Panda e cols., 2003).

Nos estudo das projeções visuais envolvidas com a mascaragem, têm-se avaliado o papel do córtex visual, colículo superior, núcleos geniculado lateral e supraquiasmático sem se obter dados que demonstrassem que alguma dessas áreas fosse necessária para a mascaragem negativa. Aliás, lesões nessas estruturas, aumentaram ainda mais a imobilidade na presença de luz (Morin e Allen, 2005). No entanto, os animais com lesões do núcleo geniculado dorsolateral não exibiram mascaragem positiva, ou seja, não apresentaram aumento da atividade como resposta a uma luminosidade tênue, observada nos animais intactos (Edelstein e Mrosovsky, 2001). Os autores apóiam a hipóteses de que os efeitos da inibição locomotora pela luz compreenderiam dois processos: um que aumentaria a atividade (mascaragem positiva) e seria controlado pelo sistema visual clássico (formação de imagens) e um outro que suprimiria a atividade (mascaragem negativa) e seria regulado pelo sistema visual de detecção de luminosidade (não o de formação de imagens).

\section{Labirinto em Cruz Elevado}

O labirinto em cruz elevado é um dos modelos mais representativos nas investigações comportamentais sobre ansiedade, já que representa com vantagens situações encontradas no ambiente natural dos animais, sem requerer aprendizagem nem condições prévias ao teste. A essência comportamental do modelo fundamenta-se nas observações e conclusões dos experimentos iniciados por Montgomery (1955). Esse autor observou uma menor utilização dos braços abertos em relação a braços circundados por paredes de seu aparato e levantou a hipótese de que a estimulação provocada pela novidade (o ambiente novo) produzia reações de conflito entre medo e curiosidade evidenciadas como tendências à esquiva e aproximação, respectivamente. (Montgomery e Monkman, 1955). Estudos farmacológicos baseados nesses resultados levaram à proposta do que hoje se conhece como o labirinto em cruz elevado (Handley 
e Mithani, 1984). O modelo é considerado um instrumento útil para se medir ansiedade, investigando aspectos comportamentais, fisiológicos e farmacológicos (Cruz e cols., 1994; Rodgers e Cole, 1994; Anseloni e Brandão, 1997). Desses pontos de vista, foi validado tanto para ratos (Pellow e cols., 1985) como para camundongos (Lister, 1990).

O teste consiste em colocar o animal em um labirinto formado por dois braços fechados por paredes e dois abertos para o ambiente, e analisar a freqüência de entradas e o tempo gasto em cada tipo de braço, juntamente com a freqüência e tempo gasto em outros comportamentos como levantar-se, esticar-se etc. Em geral, os animais apresentam uma ocupação preferencial dos braços fechados, tanto no número de entradas quanto no tempo gasto nesses braços. Considera-se a proporção da preferência (entradas e tempo gasto) pelos braços abertos e fechados um índice fidedigno de ansiedade: quanto maiores os níveis de ansiedade, menor a porcentagem de entradas nos braços abertos e de tempo gasto nos mesmos (Handley e Mithani, 1984; Pellow e File, 1986). Estudos indicam que as entradas no braço fechado representariam um índice fidedigno dos níveis de atividade geral ou locomoção (Pellow, 1986).

\section{Efeito da luminosidade sobre o comportamento de ratos testados no labirinto em cruz elevado}

Diversos fatores podem influenciar o comportamento dos ratos no labirinto (para uma revisão, ver Hogg, 1996) e um deles, como mostrado a seguir, é a luminosidade da sala experimental. De um modo geral, a maioria dos autores relata que a luminosidade provoca alterações no comportamento exploratório exibido pelo animal neste aparelho, em comparação com animais testados no escuro. Quando os animais são testados no labirinto em cruz elevado com baixos níveis de luminosidade ocorre um aumento da exploração dos braços abertos (Gentsch e cols., 1982; Morato e Castrechini, 1989; Griebel e cols., 1993; Cardenas e cols.2001; Garcia e cols., 2005). Já no caso de outros testes comportamentais, King e Jones (2001) relataram que níveis mais altos de luminosidade não alteram o comportamento de ratos no campo aberto, na tábua de buracos e nem labirinto instável, mas quando o teste é realizado no escuro, observa-se um aumento na atividade locomotora. Nasello e cols. (1998), estudaram os efeitos da escuridão repentina na resposta motora espontânea no campo aberto e no comportamento exploratório no labirinto em cruz elevado. Neste ultimo aparelho, os animais mostraram um aumento no número de entradas e tempo gasto nos braços abertos e no total de entradas. Além disso, relataram posteriormente (Nasello e cols., 
2003) que a escuridão repentina, no labirinto em cruz elevado, aumentou a freqüência total dos comportamentos de auto limpeza espontânea e o a auto limpeza genital em ratos machos mas não em fêmeas.

O papel da luminosidade, no entanto, parece ser do tipo tudo-ou-nada. Em um estudo com três níveis de luminosidade (30, 300 e 900 lux), Becker e Grecksch (1996) concluírem que o comportamento exploratório é independente dos níveis de luminosidade. Nessa linha de raciocínio, Garcia e cols. (2005), em um estudo realizado em nosso laboratório, testaram ratos no labirinto em cruz elevado com intensidades luminosas de $0,1,3,10,30$ e 300 lux e relataram que luminosidades iguais ou superiores a 3 lux produziram aversão aos braços abertos, enquanto 0 (escuro) e 1 lux produziram exploração semelhante dos braços abertos e fechados.

Martinez e cols. (2002), investigaram a função de bordas transparentes de diferentes alturas $(1,5,10,20$ e $40 \mathrm{~cm})$ circundando os braços abertos. Além dessas, a parede transparente de $40 \mathrm{~cm}$ foi também recoberta com papel branco translúcido ou preto opaco. Os animais evitaram os braços abertos circundados por paredes transparentes de 1 e $40 \mathrm{~cm}$ (note-se que as últimas permitiam tigmotaxia, pois tinham a mesma altura das paredes de madeira dos braços fechados mas permitiam a visão desimpedida). Além disso, quando as paredes transparentes de $40 \mathrm{~cm}$ foram cobertas com os papéis branco ou preto houve diminuição da aversão aos braços abertos com conseqüente aumento no comportamento exploratório, maior com o papel preto e menor com o branco, indicando que a visão (propiciada pela luminosidade) pode ser a responsável pela aversão e pela diminuição da exploração dos braços abertos.

Outros estudos do nosso laboratório mostraram que ratos testados no labirinto em cruz elevado sob condições de escuridão (0 lux), apresentam um comportamento semelhante ao de ratos testados com drogas ansiolíticas na condição de iluminação (40 lux), aumentando a exploração dos braços abertos e a locomoção em geral. Além disso, nesse estudo, o comportamento de ratos testados no escuro sob efeito de drogas ansiolíticas e ansiogênicas não difere do comportamento de animais controle (García e cols., 2006, manuscrito em preparação).

\section{Considerações sobre ansiedade}

Gray e McNaughton (2000), em uma revisão, propõem uma arquitetura simples para os sistemas de defesa com base em duas dimensões. A primeira delas estabelece uma diferença funcional entre os comportamentos que afastam o animal da fonte de 
perigo e aqueles que permitem ao animal se aproximar. Essas duas funções seriam executadas por dois sistemas neurais paralelos, um controlando o medo e o outro controlando a ansiedade, respectivamente. A segunda dimensão baseia-se em uma hierarquia funcional que determinaria o comportamento apropriado em relação à distância defensiva (distância percebida do perigo). A hierarquia funcional aplica-se igualmente para medo e ansiedade, e em cada caso, estaria representada por um nível neural que controla o comportamento. Distâncias defensivas menores estariam reguladas por estruturas neurais caudais e subcorticais, enquanto distâncias maiores seriam reguladas por estruturas neurais rostrais e corticais. Nesse contexto, inclui-se um extenso número de estruturas cerebrais, desde o córtex pré-frontal até a substancia cinzenta periaquedutal. O hipotálamo medial, a amígdala e a sustância cinzenta periaquedutal dorsal constituem o principal substrato neural da integração dos estados aversivos no cérebro. Recentemente propuseram-se algumas regiões do mesencéfalo, a exemplo do colículo inferior, como parte deste sistema. De fato, quando estimuladas química ou eletricamente, essas regiões, apresentam comportamentos relacionados com medo (Brandão e cols., 2003).

\section{Proteína Fos como marcador funcional}

No final da década de oitenta, a descoberta de que ao serem estimulados, os neurônios expressam transitoriamente o proto-oncogene c-fos (Sagar e cols., 1988) acrescentou uma nova dimensão ao conceito de neuroanatomia funcional. Pela primeira vez, os cientistas lograram examinar circuitos de neurônios contidos em diversos locais do sistema nervosos central e identificar os neurônios específicos que eram ativados por um estímulo (Hoffman e Lyo, 2002). A medida da expressão da proteína Fos é um método amplamente utilizado para marcar a ativação dos neurônios com uma elevada resolução espacial em regiões do cérebro (para uma revisão, ver Morgan e Curran, 1991; Kovács, 1998; Hoffman e Lyo, 2002).

A proteína Fos, produto do proto-oncogene $c$-fos, é sintetizada nos neurônios como conseqüência (1) do aumento do cálcio intracelular, que por sua vez aumenta os níveis de AMP cíclico, ou (2) da ação de segundos mensageiros causados por alterações no ambiente do neurônio (Sheng e Greenberg, 1990; Morgan e Curran, 1991). A produção da proteína Fos ocorre como resultado da ativação dos neurônios por uma ampla gama de estímulos, tais como ação de agentes convulsantes (Barron, 1995; Andre e cols., 1998), passagem de corrente elétrica (Lamprea e cols., 2002), 
neurotransmissores (Windle e cols.,2004), estresse por imobilização (Otake e cols., 2002), dor (Harris J.A., 1998; Lehner e cols., 2004) e injeção de salina hipertônica (Xu e cols., 2003). Como a proteína Fos se mantém no núcleo do neurônio por um curto período de tempo, a marcação dessa proteína é utilizada para localizar os corpos celulares dos neurônios ativados.

A partir dessa funcional ferramenta anatômica, demonstrou-se que, em diversas áreas do cérebro, os neurônios relacionados com os mecanismos de medo e ansiedade são ativados pela exposição a estímulos ansiogênicos e pela resposta a drogas ansiogênicas (Silveira e cols., 1993; Beck e Fibiger 1995; Duncan e cols., 1996; Singewald e Sharp 2000; Singewald e cols., 2003). Trata-se, assim, de uma ótima ferramenta para fazer medidas de ansiedade, mas que necessita correlacionar-se com outros tipos de medidas para resultar em informações adequadas.

\section{Expressão de Fos em ratos testados no labirinto em cruz elevado}

Diversos núcleos do cérebro do rato foram identificados como ativos, tal como marcados pela expressão da proteína Fos, depois de se testarem os animais no labirinto em cruz elevado na presença de luz. No estudo de Silveira e cols. (1993), ratos da cepa Long Evans foram testados com iluminação durante quinze minutos no labirinto em cruz elevado. Os resultados mostraram evidências concretas da participação de diversas regiões do cérebro na ansiedade, como o complexo amigdalóide, colículo inferior, locus coeruleus, núcleos dorsal da rafe e cuneiforme, córtices piriforme e entorrinal e os núcleos da estria terminal. Em outra pesquisa, Duncan e cols. (1996) utilizaram a marcação imunohistoquímica de Fos para evidenciar quais regiões no cérebro do rato eram ativadas quando se testavam os animais em três modelos de ansiedade, dentre eles o labirinto em cruz elevado. Os resultados mostraram que o labirinto induz uma importante produção de Fos em regiões como, os córtices pré-frontal medial e piriforme, núcleo paraventricular do tálamo e matéria cinzenta periaquadutal.

Salomé e cols. (2004) testaram no campo aberto e no braço aberto do labirinto em cruz elevado duas linhagem de ratos Wistar com traços comportamentais característicos de alta ou de baixa ansiedade. Posteriormente, usaram a expressão de Fos para identificar correlações neurobiológicas desses traços de ansiedade. Nas duas linhagens de ratos, a exposição ao campo aberto ou ao braço aberto do labirinto em cruz elevado induziu a expressão de Fos em varias regiões do circuito de medo/ansiedade do cérebro. Os ratos de fenótipo ansioso exibiram um número elevado de células com 
marcação positiva para Fos no núcleo paraventricular do hipotálamo, áreas lateral e anterior hipotalámica e pré-óptica medial. Demonstrou-se pouca expressão de Fos no córtex cingulado dos ratos de alta ansiedade, quando comparados aos ratos de baixa ansiedade.

Recentemente, Beijamini e Guimarães (2006) investigaram se os neurônios localizados nas regiões relacionadas com medo e ansiedade, que sintetizam óxido nítrico, eram também ativados após exposição ao labirinto em cruz elevado. Nesse estudo, a exposição ao labirinto aumentou a expressão de Fos nos núcleos parvocelular paraventricular, lateral do hipotálamo, dorsal da Rafe e matéria cinzenta periaqüedutal dorsolateral, mas não nos núcleos do complexo amigdalóide.

\section{Expressão de Fos e luminosidade}

Pulsos de luz de baixa freqüência e intensidades de luz de 50 e 400 lux ativam a expressão de Fos em varias estruturas visuais incluindo o núcleo geniculado lateral, colículo superior e córtex visual (Correa-Lacarcel, 2000; Prichard e cols., 2002; Greferath e cols., 2004). Ratos expostos a uma intensidade de 400 lux também exibiram expressão de Fos na lâmina intergeniculada e núcleo geniculado ventrolateral além dos núcleos limitante posterior, olivar e comissural do pré-tecto (Prichard e cols., 2002). Greferath e cols. (2004) utilizaram camundongos transgênico cujos neurônios expressavam Fos no núcleo e $\beta$-galactosidase nos axônios e dendritos, permitindo assim a visualização direta das projeções, para examinar a ativação funcional do sistema visual pela luz ( $<50$ lux). Os dados mostraram a ativação do colículo superior, córtex visual primário e núcleo geniculado dorsolateral, mas não da lâmina intergeniculada nem do núcleo geniculado ventrolateral.

\section{Objetivos}

Diferentes padrões de luz atingindo a retina podem alterar o funcionamento dos sistemas que medeiam a aversão e a locomoção, Assim, o presente trabalho visou analisar o efeito da ausência de iluminação sobre a expressão da proteína Fos nas várias regiões do cérebro de ratos testados no labirinto em cruz elevado. Além disso, também se pretende diferenciar o efeito do mero manuseio da exposição a ambientes novos e o próprio papel da iluminação sobre a expressão da proteína Fos nas várias regiões do cérebro de ratos. 


\section{Materiais e Métodos}

Sujeitos. Foram utilizados ratos machos de uma derivação Wistar, com aproximadamente $240 \mathrm{~g}$ no dia do teste comportamental, provenientes do Biotério Central do Campus da Universidade de São Paulo em Ribeirão Preto. Os animais foram distribuídos em grupos de seis alojados em gaiolas de polipropileno (40 x 34 x $17 \mathrm{~cm}$ ) com água e comida à vontade, em um biotério mantido em ciclo claro-escuro de 12 horas (luzes acesas às $7 \mathrm{~h}$ da manhã), com a temperatura mantida entre 24 e $27^{\circ} \mathrm{C}$. Exceto na ocasião do teste comportamental, todos os sujeitos permaneceram no biotério, cuja condição de luminosidade era de 40 lux medidos no piso logo abaixo da lâmpada, fornecidos por um bulbo incandescente de $100 \mathrm{~W}$ colocado no centro do teto a 2,75 m do piso.

Equipamento. Utilizou-se um labirinto em cruz elevado formado por dois braços abertos protegidos por uma borda $(50 \times 10 \times 0,5 \mathrm{~cm})$ cruzados por dois braços fechados $(50 \mathrm{x}$ 10 x $40 \mathrm{~cm})$, conectados por uma área central $(10 \times 10 \mathrm{~cm})$ e elevado a $50 \mathrm{~cm}$ do piso. Uma câmara montada verticalmente acima do labirinto e acoplada a um monitor de televisão em uma sala adjacente à sala de teste permitia o registro em videoteipe e a observação direta durante o teste. No registro, a imagem do labirinto na tela do aparelho de televisão foi dividida em quadrados iguais $(10 \mathrm{~cm}$ de lado), permitindo o registro da localização precisa do animal em qualquer local do labirinto e a quantidade de quadrados atravessados pelo animal. O comportamento foi registrado com um software (X-Plo-Rat) especialmente desenvolvido no nosso laboratório para este fim.

Procedimento. Depois de um período de 72 horas de habituação ao biotério do laboratório, os animais foram distribuídos aleatoriamente em três grandes grupos conforme a situação de teste. O primeiro (a) era transportado do biotério até a sala onde ficava o labirinto em cruz elevado no qual seria testado por $5 \mathrm{~min}$. O segundo servia de controle para o primeiro e (b) era transportado do biotério até outra sala onde era colocado em uma gaiola idêntica à gaiola-viveiro por $5 \mathrm{~min}$. Cada um desses dois grupos foi subdividido em dois subgrupos de acordo com o nível de luminosidade sob o qual foi testado: 0 e 30 lux. Um terceiro e último grupo foi constituído por animais (c) mantidos no biotério na gaiola-viveiro até a morte. Dessa forma, obtiveram-se cinco grupos: Biotério (B), Gaiola no claro (GC), Gaiola no escuro (GE), Labirinto no claro (LC) e Labirinto no escuro (LE). 
Teste no labirinto em cruz elevado e condições de controle. No período do teste, utilizaram-se, além do biotério, duas salas com igual iluminação: uma sala de controle de luminosidade (grupo G) e outra contendo um labirinto em cruz elevado (grupo L). A cada teste, dois animais de uma mesma gaiola-viveiro eram retirados do biotério, um transportado para a sala de controle, outro para a sala do labirinto no qual era testado. No centro da sala de controle, havia uma gaiola colocada a $50 \mathrm{~cm}$ do piso, que recebia a luminosidade de 30 lux ou permanecia no escuro (0 lux). Na sala do labirinto (com a mesma iluminação da sala de controle), os animais eram colocados na área central do labirinto com o focinho voltado para um dos braços fechados. Deixava-se que o animal explorasse o labirinto livremente por 5 minutos. Na sala de controle, o outro rato era mantido na gaiola também por $5 \mathrm{~min}$. Durante esse período, eram registrados no labirinto: a freqüência de entradas e o tempo gasto em cada braço, bem como a freqüência e o tempo gasto nos comportamentos de mergulhar a cabeça, levantar-se nas patas traseiras, limpar-se e esticar-se. A partir do número de quadrados atravessados, estimou-se a distância percorrida em cada braço.

Terminado o teste no labirinto em cruz elevado, o animal era colocado na gaiola da sala de controle junto com rato que havia permanecido nela também por cinco minutos. A dupla permanecia por $2 \mathrm{~h}$, após o que recebia uma injeção de uretana $(1,25$ $\mathrm{mg} / \mathrm{Kg}$ ) e era submetida à perfusão. Todas as duplas eram familiares, já que foram mantidas na mesma gaiola-viveiro no biotério, para evitar o estresse do isolamento ou da interação social com um animal desconhecido. No momento da anestesia com uretana, um rato controle do biotério também era anestesiado para perfusão.

Para uma melhor interpretação dos dados, além da comparação dos grupos do teste no labirinto em cruz elevado (LC e LE), programaram-se os três outros grupos (B, GC e GE) como controles de outros fatores que também poderiam produzir expressão de Fos, como o manuseio, a exposição a um ambiente novo e a iluminação. Os animais do grupo B - os mais experimentalmente ingênuos - foram o controle de todos os grupos. A comparação dos animais dos grupos GC e LC com os animais dos grupos GE e LE permite entender o efeito da luminosidade.

Perfusão e marcação imunoistoquímica de Fos. Duas horas depois da exposição ao labirinto, os animais receberam uma injeção intraperitonial de uretana $(1,25 \mathrm{ml} / \mathrm{Kg}) \mathrm{e}$ foram submetidos à perfusão cardíaca com PBS $0,1 \mathrm{M}$, seguido de paraformaldeído 4\%. Os encéfalos foram removido e imersos em uma solução de paraformaldeído durante 2 
horas e então fixados. Em seguida, foram transferidos para uma solução de sacarose $30 \%$ em PBS 0,1 M, para crioproteção, onde permaneceram por 24 horas. Os encéfalos foram congelados em isopentano $\left(-40^{\circ} \mathrm{C}\right)$ e, com o uso de um criostato $\left(-17^{\circ} \mathrm{C}\right)$, foram obtidas secções transversais $(40 \mu \mathrm{m})$. As secções de tecido foram coletadas em PBS 0,1 M. e posteriormente, processadas segundo o protocolo Avidina Biotina com o kit IgG Vectastain ABC peroxidase (Vector; ref: PK 6101). As secções foram inicialmente incubadas com $\mathrm{H}_{2} \mathrm{O}_{2} 1 \%$, submetidas a 4 lavagens de 5 minutos com PBS e posteriormente, incubadas sob agitação, por 16 horas, à temperatura ambiente, em anticorpo primário c-fos (SC-52 policlonal produzido em coelho, Santa Cruz Biotecnology) em uma concentração de 1:2000 em PBS 0,1 M., Triton-X 0,2 \% e albumina bovina. Depois de três lavagens de 5 minutos com PBS, as secções foram novamente incubadas por 1 hora, sob agitação e temperatura ambiente em anticorpo secundário bionitilado anti-IgG de coelho $(\mathrm{H}+\mathrm{L})$, produzido em cavalo (Vector Laboratories) em uma concentração de 1:400 de PBS 0,1 M., Triton-X 0,2 \% e albumina bovina. Depois de outra serie de três lavagens de 5 minutos com PBS, as secções foram incubadas durante uma hora, à temperatura ambiente, em solução Avidina-Biotina-peroxidase em PBS 0,1 M.. Depois desse período, as secções foram lavadas mais três vezes com PBS. Para a revelação utilizou-se uma solução de 3,3'diaminobenzidina (DAB 0,05\%), adicionando-se peroxidase hidrogenada $(0,01 \%)$. A reação ocorreu a temperatura ambiente durante 5-8 minutos. As secções foram lavadas duas vezes com PBS para interromper a reação.

Como controle da imunoistoquímica, utilizaram-se cortes do cérebro de um animal que, duas horas antes da perfusão, recebeu uma injeção intraperitonial de pentilenotetrazol $(60 \mathrm{mg} / \mathrm{Kg})$, droga convulsiva, inibidora de neurotransmissão GABAérgica (Dragunow e Faull, 1989, Sagar e cols., 1988).

Contagem de células. As secções de tecido foram montadas sobre lâminas gelatinizadas, desidratadas, cobertas por lamínulas e fotografadas com ajuda de um microscópio (Olympus BX-50) equipado com câmera digital (Hamatsu Photonics C2400). Os núcleos de neurônios que reagiram ao DAB no tecido foram contados automaticamente de acordo com o método utilizado por Lamprea e cols. (2001). Para isso, utilizou-se um sistema computadorizado de análises de imagens (Image Pro Plus 5.0, Media Cybernetics, USA). A contagem de células positivas para fos, realizou-se com uma ampliação de 100 vezes. Objetos escuros com áreas entre 10 e $80 \mu \mathrm{m}^{2}$ foram identificados como células que marcaram Fos. Para cada animal, utilizou-se uma área da 
mesma forma e tamanho para cada região do cérebro e padronizaram-se os planos analisado tanto quanto possível. A nomenclatura e as dimensões dos núcleos foi baseada no Atlas de Paxinos e Watson (1997). Todas as regiões do cérebro foram contadas bilateralmente nas secções de cada animal. Os núcleos foram contados individualmente e o resultado expressou-se como densidade neuronal, ou seja, o número de neurônios positivos para Fos em 0,1 $\mathrm{mm}^{2}$ (Lamprea e cols., 2001). Os cortes tiveram como referência as seguintes coordenadas no sentido antero-posterior em relação ao bregma: 2.7, $0.7,1.00,-0.30,-1.30,-1.80,-3.14,-4.80,-6.04,-8.00,-9.68 \mathrm{~mm}$, segundo Atlas Paxinos e Watson (1997).

Algumas das estruturas analisadas neste trabalho foram estudadas anteriormente por Silveira e cols. (1993) e por Duncan e cols. (1996). Incluem-se ademais alguns núcleos envolvidos com o sistema visual.

Tratamento Estatístico. Os resultados comportamentais obtidos foram submetidos ao teste $t$ de Student para amostras independentes. Os resultados imunoistoquímicos, foram submetidos a uma análise de variância (Anova) de uma via seguida, sempre que apropriado pelo teste de post hoc de Dunnett, de comparações de médias de grupos com um grupo controle, para detecção de quaisquer diferenças com os dados do grupo que permaneceu no biotério. Sempre que se detectava qualquer diferença com esses animais do biotérios, os demais eram submetidos a uma Anova de duas vias, com iluminação como um dos fatores (dois níveis: claro e escuro) e ambiente como o outro (dois níveis: caixa e labirinto). Neste segundo caso, utilizou-se o teste post hoc de Student-NewmanKeuls, para comparações múltiplas de médias de grupos. Adicionalmente, utilizou-se o teste de Spearman, para estabelecer coeficientes de correlação entre o número de neurônios marcados por Fos e medidas comportamentais no labirinto em cruz elevado. Em todos os casos, valores de $\mathrm{P}$ iguais ou inferiores a 0,05 foram considerados significativos. 


\section{Resultados}

\section{Comportamento no labirinto em cruz elevado}

A Tabela 1 resume os valores das medidas comportamentais obtidas no labirinto em cruz elevado. As medidas de ansiedade relacionam-se com a exploração dos braços abertos e as medidas de locomoção com a exploração dos braços fechados.

Consideraram-se também outras medidas de atividade.

Tabela 1. Valores das medidas comportamentais (média \pm EPM) no labirinto em cruz elevado e de $t$ para 12 graus de liberdade.

Os ratos foram expostos ao labirinto em cruz elevado na ausência ou presença de luz. Para cada comportamento realizou-se uma comparação nas condições de iluminação (teste $t$ para amostras independentes). Para ambos grupos $\mathrm{N}=7$. *, significativamente diferente do controle no claro.

\begin{tabular}{|c|c|c|c|c|}
\hline \multirow[b]{3}{*}{ Medida comportamental } & \multicolumn{2}{|c|}{ Labirinto } & & \\
\hline & \multirow{2}{*}{$\frac{\text { Claro }}{\text { média } \pm \text { EPM }}$} & \multirow{2}{*}{$\frac{\text { Escuro }}{\text { média } \pm \text { EPM }}$} & \multicolumn{2}{|c|}{ Teste $t$ de Student } \\
\hline & & & $\mathrm{T}_{(12)}$ & $\mathrm{P}$ \\
\hline \multicolumn{5}{|c|}{ Braços abertos } \\
\hline Porcentagem de entradas & $33,2 \pm 2,86$ & $56,7 \pm 3,73^{*}$ & 5,010 & 0,001 \\
\hline Tempo gasto (s) & $35,9 \pm 5,4$ & $122,5 \pm 13,2 *$ & 6,072 & 0,001 \\
\hline Entradas nas extremidades & $2,1 \pm 0,7$ & $9,1 \pm 1,4^{*}$ & 4,589 & 0,001 \\
\hline Tempo nas extremidades & $12,1 \pm 4,1$ & $57,7 \pm 9,6^{*}$ & 4,380 & 0,001 \\
\hline Distancia percorrida (m) & $2,0 \pm 0,5$ & $7,5 \pm 0,9 *$ & 5,324 & 0,001 \\
\hline Freqüência de esticadas & $0,7 \pm 0,4$ & $1,3 \pm 1,1$ & 0,475 & 0,644 \\
\hline Freqüência de mergulhos de cabeça & $3,4 \pm 0,9$ & $8,3 \pm 1,7^{*}$ & 2,480 & 0,029 \\
\hline \multicolumn{5}{|c|}{ Braços fechados } \\
\hline Freqüência de entradas & $6,6 \pm 0,7$ & $9,0 \pm 1,4$ & 1,592 & 0,137 \\
\hline Tempo gasto (s) & $238,9 \pm 9,7$ & $138,7 \pm 10,9 *$ & 6,878 & 0,001 \\
\hline Entradas nas extremidades & $8,1 \pm 0,6$ & $8,1 \pm 0,9$ & 0.000 & 1,000 \\
\hline Tempo nas extremidades & $123,3 \pm 20,6$ & $78,5 \pm 7,8$ & 2,033 & 0,065 \\
\hline Distancia percorrida (m) & $6,6 \pm 0,4$ & $6,9 \pm 0,9$ & 0,277 & 0,787 \\
\hline Freqüência de esticadas & $3,6 \pm 1,2$ & $1,6 \pm 0,7$ & 1,454 & 0,172 \\
\hline Freqüência de mergulhos de cabeça & $0,1 \pm 0,1$ & $0,4 \pm 0,2$ & 1,115 & 0,271 \\
\hline \multicolumn{5}{|c|}{ Outros } \\
\hline Tempo gasto no centro (s) & $25,2 \pm 6,5$ & $38,8 \pm 4,9$ & 1,668 & 0,121 \\
\hline Freqüência total de levantadas & $22,0 \pm 2,9$ & $18,0 \pm 2,2$ & 1,080 & 0,301 \\
\hline Tempo total gasto levantando-se (s) & $32,7 \pm 5,5$ & $32,2 \pm 4,0$ & 0,072 & 0,944 \\
\hline Freqüência total de limpadas & $8,1 \pm 1,5$ & $4,6 \pm 1,8$ & 1,531 & 0,152 \\
\hline Tempo gasto limpando-se (s) & $39,4 \pm 13,1$ & $21,8 \pm 4,6$ & 1,265 & 0,230 \\
\hline
\end{tabular}

O resultado do teste $t$ para amostras independentes mostrou que os animais testados no escuro exibem maior exploração dos braços abertos, comparados com os animais testado no claro. Assim, quando testados no escuro, os animais aumentaram significativamente a porcentagem de entradas, o tempo, as entradas nas extremidades, a distância percorrida e a freqüência de mergulhos nos braços abertos (ver Tabela 1). Porém, não foram observadas diferenças no tempo de mergulhos $\left(t_{[12]}=2,071 ; \mathrm{P}<\right.$ 
$0,061)$, freqüência de esticadas $(t[12]=0,475 ; \mathrm{P}<0,644)$, nem no tempo de esticadas $\left(t_{[12]}=0,629 ; \mathrm{P}<0,541\right)$ nesses braços.

Os animais testados no escuro exibiram diminuição significativa no tempo de permanência nos braços fechados, comparado com os animais testados no claro (Tabela 1). No entanto, os resultados não indicaram diferencias significativas no número de entradas, entradas nas extremidades, distância percorrida, freqüência e tempo de esticadas e mergulhos nos braços fechados (ver Tabela 1). Animais testados no claro e no escuro não exibiram diferenças no tempo de permanência na plataforma central, freqüência e tempo de levantadas e freqüência e tempo de limpação (Tabela 1).

$\mathrm{O}$ aumento significativo na porcentagem de entradas e no tempo de permanência nos braços abertos (Figura 1), assim como nas entradas e tempo de permanência nas extremidades abertas (Figura 2), indicam uma diminuição da ansiedade nos animais testados no escuro. No entanto, as medidas semelhantes no número de entradas e na distância percorrida nos braços fechados (Figura 3), indicam que a locomoção dos animais testados no labirinto, permanece constante na presença ou ausência de iluminação.
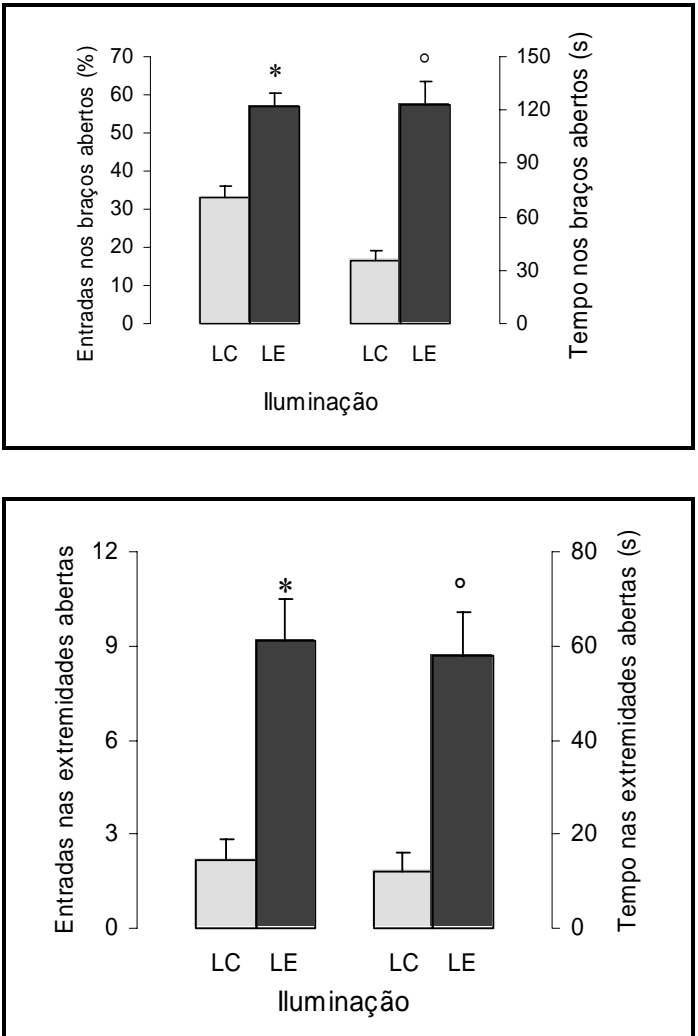

Figura 1. Porcentagem de entradas e tempo de permanência nos braços abertos do labirinto em cruz elevado.

Os animais foram testados em um ambiente claro (LC) com uma iluminação de 30 lux, ou em um ambiente escuro (LE) de 0 lux. *, $\mathrm{t}_{(12)}=5,010 ; \mathrm{P}<0,001 ;{ }^{\circ}, \mathrm{t}_{(12)}=$ 6,$072 ; \mathrm{P}<0,001$.

Figura 2. Número de entradas e tempo de permanência nas extremidades dos braços abertos do labirinto em cruz elevado.

Os animais foram testados em um ambiente claro (LC) com uma iluminação de 30 lux, ou em um ambiente escuro (LE) de 0 lux. *, $\mathrm{t}(12)=4,589 ; \mathrm{P}<0,001 ;{ }^{\circ}, \mathrm{t}(12)=$ 4,589; $\mathrm{P}<0,001$. 


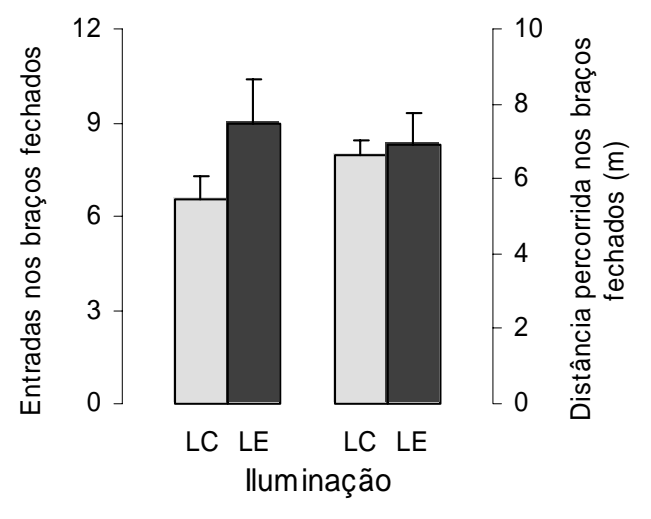

Figura 3. Número de entradas e distância percorrida nos braços fechados do labirinto em cruz elevado.

Os animais foram testados em um ambiente claro (LC) com uma iluminação de 30 lux, ou em um ambiente escuro (LE) de 0 lux.

\section{Expressão da proteína Fos}

A Tabela 2 mostra o número total de neurônios que expressaram a proteína Fos em diferentes regiões do cérebro de ratos, após serem colocados em uma gaiola-viveiro no claro (GC) e no escuro (GE) e no labirinto em cruz elevado no claro (LC) e no escuro (LE). Os dados representam-se como a média ( \pm E.P.M.) das células que marcaram Fos em uma área de $0,1 \mathrm{~mm}^{2}$ de tecido. As fotomicrografias dos tecidos encontram-se no Apêndice e representam-se nas Figuras 12 e 13.

Mostram-se igualmente na tabela, os resultados da Anova de uma via que foi seguida, sempre que apropriado pelo teste de post hoc de Dunnett, para detecção de quaisquer diferenças com os dados do grupo (B) que permaneceu no biotério. Os valores de $\mathrm{P}$ iguais ou inferiores a 0,05 foram considerados significativos.

Os animais que permaneceram no biotério exibiram baixa expressão de Fos na maioria das estruturas analisadas, exceto em alguns núcleos do diencéfalo. A expressão de Fos na área pré-óptica do hipotálamo, por exemplo, foi maior que nos animais transportados dos grupos GC e GE. (Tabela 2). A marcação no núcleo lateral anterior do hipotálamo foi maior nos ratos do grupo B que nos outros grupos. (Tabela 2). A marcação no núcleo paraventricular anterior do tálamo foi semelhante à marcação de ratos testados no escuro, tanto na gaiola como no labirinto (Tabela 2). A mesma coisa foi observada também no núcleo pré-tectal olivar do mesencéfalo.

Os animais que foram transportados das suas gaiolas-viveiro para uma sala e expostos a uma outra gaiola-viveiro, durante 5 minutos, exibiram aumento na expressão de Fos. Mas esse aumento não foi significativo comparado com os animais do biotério. 
Tabela 2. Expressão da proteína Fos (média \pm E.P.M., células $/ 0,1 \mathrm{~mm}^{2}$ ) em diferentes regiões do cérebro de ratos expostos a uma gaiola-viveiro ou ao labirinto em cruz elevado na presença e ausência de iluminação e resultados da análise de variância.

*, Diferente do biotério (Dunnett, $P<0,05$ ).

\begin{tabular}{|c|c|c|c|c|c|c|c|c|}
\hline \multirow[b]{2}{*}{ Estruturas } & \multirow[b]{2}{*}{ Biotério } & \multicolumn{2}{|c|}{ Gaiola } & \multicolumn{2}{|c|}{ Labirinto em cruz elevado } & \multicolumn{3}{|c|}{ Anova } \\
\hline & & Claro & Escuro & Claro & Escuro & g. I. & $\mathrm{F}$ & $\mathrm{P}$ \\
\hline & \multicolumn{8}{|c|}{ Telencéfalo } \\
\hline Córtex cingulado anterior & $1,77 \pm 0,81$ & $5,91 \pm 1,19 *$ & $6,12 \pm 0,99 *$ & $7,05 \pm 0,94 *$ & $8,44 \pm 0,44^{*}$ & 4,26 & 6,992 & $<0,001$ \\
\hline Córtex prelímbico & $2,68 \pm 1,07$ & $5,43 \pm 1,52$ & $5,47 \pm 1,44$ & $8,74 \pm 1,12^{*}$ & $5,70 \pm 0,86$ & 4,24 & 3,206 & 0,030 \\
\hline Córtex infralímbico & $3,01 \pm 1,42$ & $7,19 \pm 2,12$ & $4,42 \pm 1,65$ & $7,26 \pm 1,21$ & $3,82 \pm 0,64$ & 4,23 & 1,946 & 0,137 \\
\hline Córtex piriforme & $4,29 \pm 1,00$ & $4,52 \pm 1,52$ & $5,22 \pm 1,46$ & $5,22 \pm 1,18$ & $17,21 \pm 4,16 *$ & 4,24 & 4,423 & 0,008 \\
\hline Área septal lateral & $0,47 \pm 0,22$ & $3,90 \pm 1,23$ & $2,10 \pm 0,90$ & $4,87 \pm 1,24 *$ & $1,84 \pm 0,52$ & 4,24 & 3,570 & 0,020 \\
\hline Amígdala central & $0,79 \pm 0,31$ & $1,23 \pm 0,17$ & $1,89 \pm 0,52$ & $1,25 \pm 0,24$ & $2,62 \pm 0,29 *$ & 4,25 & 4,741 & 0,006 \\
\hline Amígdala medial & $0,99 \pm 0,43$ & $1,85 \pm 0,41$ & $1,43 \pm 0,69$ & $1,16 \pm 0,27$ & $5,35 \pm 0,72 *$ & 4,24 & 11,680 & $<0,001$ \\
\hline Amígdala lateral & $1,09 \pm 0,35$ & $1,62 \pm 0,55$ & $0,72 \pm 0,20$ & $1,04 \pm 0,16$ & $3,58 \pm 0,90 *$ & 4,25 & 5,322 & 0,003 \\
\hline \multirow[t]{2}{*}{ Amígdala basolateral } & $0,75 \pm 0,24$ & $1,32 \pm 0,39$ & $0,65 \pm 0,16$ & $1,29 \pm 0,25$ & $3,94 \pm 0,78^{*}$ & 4,24 & 9,991 & $<0,001$ \\
\hline & \multicolumn{8}{|c|}{ Diencéfalo } \\
\hline Núcleo septohipotalámico & $4,28 \pm 1,68$ & $5,97 \pm 1,34$ & $4,36 \pm 1,10$ & $5,63 \pm 0,92$ & $5,34 \pm 0,77$ & 4,24 & 0,337 & 0,850 \\
\hline Núcleo preóptico & $6,90 \pm 2,27$ & $8,75 \pm 1,73$ & $6,18 \pm 1,38$ & $9,09 \pm 1,24$ & $7,58 \pm 1,41$ & 4,23 & 0,599 & 0,667 \\
\hline Hipotálamo lateral anterior & $9,56 \pm 0,91$ & $7,20 \pm 0,68$ & $9,06 \pm 1,64$ & $8,04 \pm 0,77$ & $3,65 \pm 0,74 *$ & 4,21 & 6,896 & 0,001 \\
\hline Hipotálamo área anterior central & $4,17 \pm 0,95$ & $4,35 \pm 1,38$ & $7,04 \pm 2,67$ & $4,96 \pm 0,48$ & $11,06 \pm 2,30 *$ & 4,22 & 3,519 & 0,023 \\
\hline Hipotálamo paraventricular & $4,14 \pm 0,28$ & $3,67 \pm 0,73$ & $4,23 \pm 0,83$ & $4,05 \pm 0,40$ & $5,37 \pm 1,03$ & 4,23 & 0,894 & 0,483 \\
\hline Hipotálamo dorsomedial & $3,33 \pm 0,47$ & $3,84 \pm 0,89$ & $3,11 \pm 0,46$ & $3,70 \pm 0,66$ & $6,12 \pm 0,82 *$ & 4,27 & 3,651 & 0,017 \\
\hline Núcleo supramamilar & $3,90 \pm 1,83$ & $4,61 \pm 0,43$ & $6,45 \pm 1,09$ & $6,73 \pm 0,99$ & $6,43 \pm 0,76$ & 4,25 & 1,151 & 0,356 \\
\hline Tálamo paraventricular anterior & $7,55 \pm 2,36$ & $10,13 \pm 2,67$ & $6,19 \pm 1,56$ & $11,72 \pm 1,40$ & $8,77 \pm 0,89$ & 4,24 & 1,557 & 0,218 \\
\hline Tálamo paraventricular posterior & $7,59 \pm 1,26$ & $9,16 \pm 2,86$ & $7,46 \pm 2,08$ & $8,90 \pm 1,29$ & $10,35 \pm 1,62$ & 4,24 & 0,417 & 0,795 \\
\hline Lâmina intergeniculada & $4,32 \pm 1,59$ & $8,36 \pm 1,88$ & $3,84 \pm 1,20$ & $11,39 \pm 1,96^{*}$ & $3,78 \pm 0,80$ & 4,28 & 6,536 & $<0,001$ \\
\hline Núcleo peripeduncular & $1,45 \pm 0,49$ & $3,08 \pm 0,24$ & $1,34 \pm 0,58$ & $3,42 \pm 0,83$ & $2,12 \pm 0,53$ & 4,22 & 2,260 & 0,095 \\
\hline \multirow[t]{2}{*}{ Núcleo suprageniculado } & $1,56 \pm 0,17$ & $2,34 \pm 0,60$ & $5,58 \pm 0,91$ & $3,75 \pm 1,07$ & $2,39 \pm 0,33$ & 4,21 & 1,352 & 0,284 \\
\hline & \multicolumn{8}{|c|}{ Tronco cerebral } \\
\hline PAG dorsomedial & $2,23 \pm 0,76$ & $4,10 \pm 0,81$ & $3,36 \pm 0,93$ & $4,96 \pm 1,16$ & $2,65 \pm 0,19$ & 4,22 & 1,610 & 0,207 \\
\hline PAG dorsolateral & $4,79 \pm 1,79$ & $6,50 \pm 1,81$ & $6,60 \pm 2,09$ & $7,94 \pm 1,65$ & $5,16 \pm 0,88$ & 4,22 & 0,548 & 0,703 \\
\hline PAG lateral & $3,84 \pm 1,14$ & $4,16 \pm 1,30$ & $3,61 \pm 0,94$ & $3,41 \pm 0,82$ & $7,82 \pm 1,54$ & 4,23 & 2,600 & 0,063 \\
\hline Colículo superior camadas superf. & $0,63 \pm 0,36$ & $1,94 \pm 0,43$ & $1,18 \pm 0,25$ & $2,02 \pm 0,69$ & $2,69 \pm 0,98$ & 4,19 & 1,047 & 0,409 \\
\hline Colículo superior camadas profundas & $1,44 \pm 0,59$ & $4,26 \pm 0,86$ & $3,13 \pm 0,72$ & $4,78 \pm 1,28$ & $5,54 \pm 1,77$ & 4,19 & 1,093 & 0,388 \\
\hline Núcleo olivar pré-tectal & $3,00 \pm 1,27$ & $4,60 \pm 1,79$ & $2,57 \pm 0,79$ & $5,94 \pm 0,79$ & $2,23 \pm 0,25$ & 4,21 & 3,034 & 0,040 \\
\hline Núcleo Dorsal da Rafe & $0,23 \pm 0,09$ & $0,68 \pm 0,29$ & $0,77 \pm 0,14$ & $1,01 \pm 0,26$ & $1,18 \pm 0,41$ & 4,19 & 1,475 & 0,249 \\
\hline Núcleo Mediano da Rafe & $0,77 \pm 0,13$ & $1,60 \pm 0,47$ & $1,98 \pm 0,12$ & $2,23 \pm 0,35$ & $3,38 \pm 0,75^{*}$ & 4,19 & 5,050 & 0,006 \\
\hline Locus coeruleus & $2,34 \pm 0,68$ & $2,47 \pm 0,26$ & $3,05 \pm 0,29$ & $4,30 \pm 0,80$ & $5,53 \pm 0,94 *$ & 4,16 & 3,453 & 0,032 \\
\hline
\end{tabular}


O único aumento significativo observou-se no córtex cingulado anterior, tanto no claro como no escuro (Tabela 2).

Ratos expostos ao labirinto em cruz elevado exibiram aumento significativo na expressão de Fos em 14 das 30 estruturas estudadas, quando comparados com os animais mantidos no biotério (Tabela 2). A maioria dos aumentos significativos foram observados nos ratos testados no escuro. Os núcleos da amígdala mostraram um padrão comum de aumento na expressão de Fos nos ratos do grupo LE (Tabela 2).

A Figura 4 ilustra a expressão de Fos em alguns núcleos do telencéfalo. Mostram-se o córtex piriforme anterior (bregma: 2,7), a área septal lateral (bregma: 0.7) e o córtex pré-frontal medial (bregma: 0,7), formado pelo córtex cingulado anterior, o córtex pré-límbico e infralímbico. Para as cinco estruturas mostradas, cada grupo foi composto por um número de sujeitos correspondente a: $\mathrm{B}(\mathrm{n}=5), \mathrm{GC}(\mathrm{n}=4$ 5), GE $(n=6), \operatorname{LC}(n=7-8)$ e LE $(n=6-7)$. Em geral, as regiões corticais mostram aumento na expressão de Fos. Nota-se um incremento significativo no córtex cingulado anterior em qualquer tipo de condição na que os animais foram expostos (ver Tabela 2). Evidencia-se o aumento significativo de Fos no córtex piriforme nos animais testados no LE, o que contrasta com a marcação do córtex infralímbico e a área septal lateral, regiões que mostram aumento significativo nos animais testados no LC.

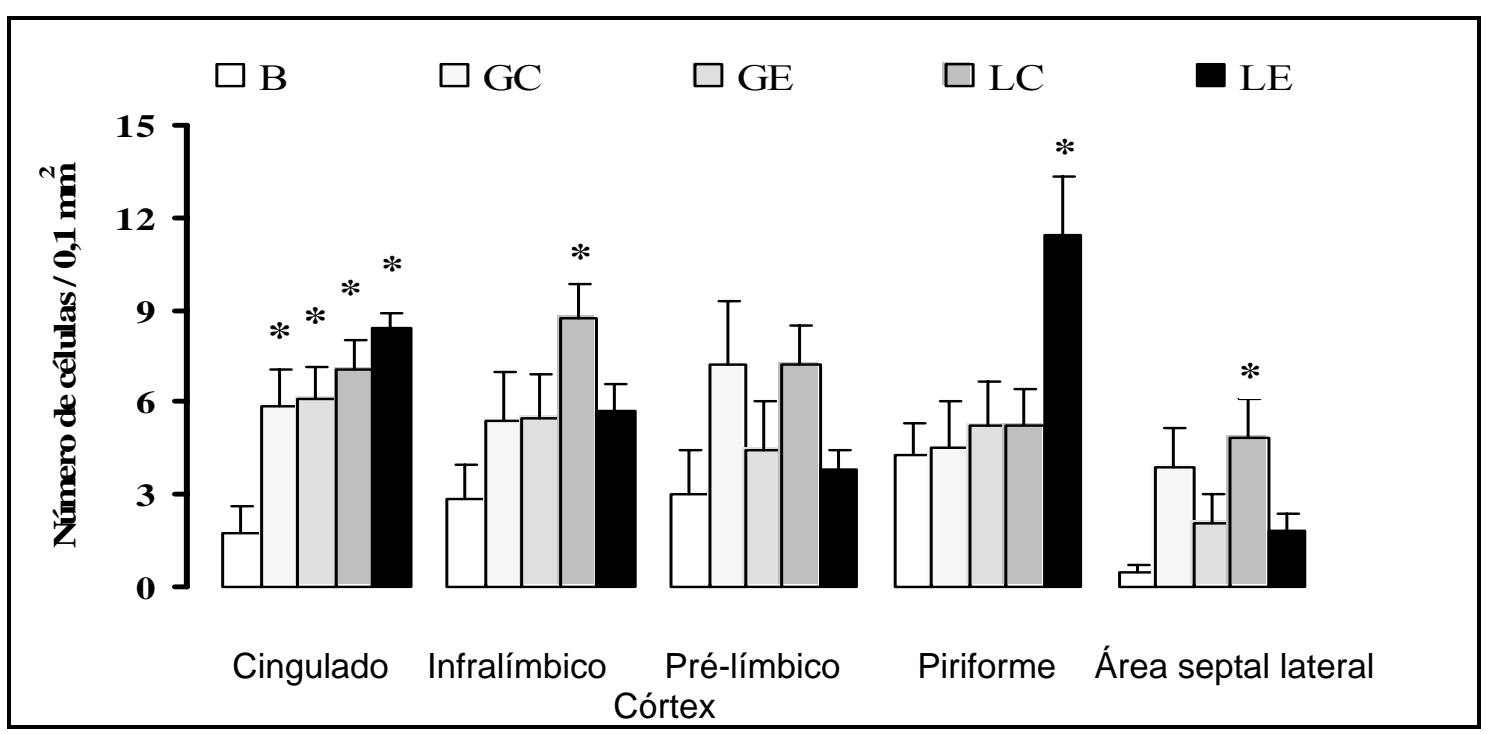

Figura 4. Expressão da proteína Fos (células $/ 0,1 \mathrm{~mm}^{2}$, média \pm E.P.M.) no telencéfalo. * Diferente do grupo B (Dunnett, $p<0,05$ )

A Figura 5 ilustra a expressão de Fos (média \pm E.P.M., células $/ 0,1 \mathrm{~mm}^{2}$ ), em núcleos da amígdala, pertencentes à região do telencéfalo. Mostram-se os núcleos da amígdala lateral (bregma: -3,14), basolateral (bregma: -3,14) central (bregma: -3,14) e 
medial (bregma: -3,14). Para as quatro estruturas mostradas, cada grupo foi composto por um número de sujeitos correspondente a: $\mathrm{B}(\mathrm{N}=5), \mathrm{GC}(\mathrm{N}=5), \mathrm{GE}(\mathrm{N}=6), \mathrm{LC}$ $(\mathrm{N}=7)$ e LE $(\mathrm{n}=6-7)$. A pesar do número reduzido de células, comparados com outros núcleos do telencéfalo, evidencia-se aumento significativo de Fos nos quatro núcleos ilustrados, quando os animais foram testados no LE.

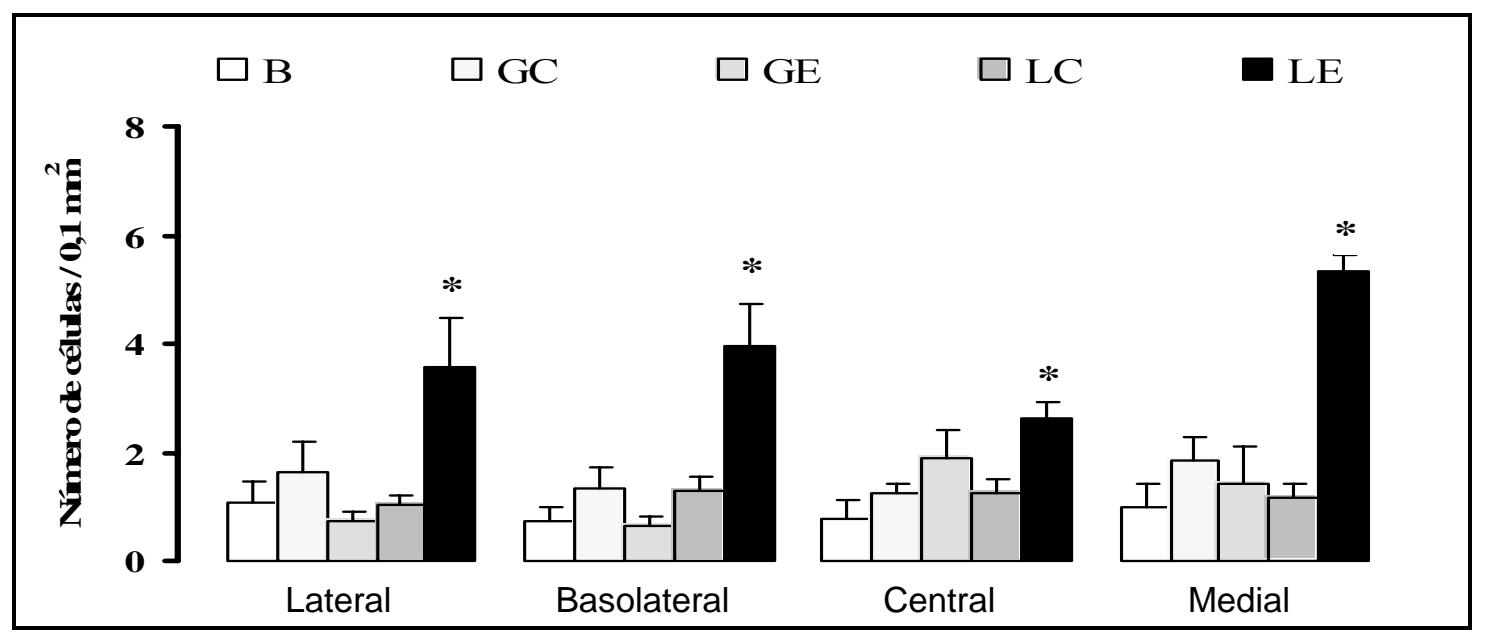

Figura 5. Expressão da proteína Fos na amígdala (células $/ 0,1$ mm², média \pm E.P.M.). *, Diferente do grupo B (Dunnett, $p<0,05$ )

A Figura 6 mostra a expressão de Fos (média \pm E.P.M., células $/ 0,1 \mathrm{~mm}^{2}$ ) em núcleos do diencéfalo, pertencentes à região do hipotálamo. Ilustram-se os núcleos Septohipotalámico, (bregma: -0,30), Hipotálamo Lateral anterior, (bregma: -1,30), Paraventricular (bregma: -1,80), Dorsomedial (bregma: -3,14) e Supramamilar (bregma: -4,80) e as áreas pré-óptica (bregma: -0,30) e anterior central (bregma: -1,80). Para as quatro estruturas mostradas, cada grupo foi composto por um número de sujeitos correspondente a: B $(\mathrm{N}=4-6), \mathrm{GC}(\mathrm{N}=4-6), \mathrm{GE}(\mathrm{N}=4-7), \mathrm{LC}(\mathrm{N}=6-7)$ e LE $(\mathrm{N}=6-7)$. A marcação de Fos nos núcleos do hipotálamo foi mais heterogênea comparada com o padrão de marcação da amígdala. Contrastam os resultados de duas estruturas anteriores nos ratos testados no labirinto. No grupo LC, a marcação no hipotálamo lateral anterior exibiu diminuição significativa, em quanto que a área anterior central mostrou aumento significativo no LE (Tabela 2). Comparados com o grupo B, os animais do grupo LE exibiram aumento significativo de Fos no hipotálamo dorsomedial (Tabela 2). A Anova não mostrou diferenças significativas nos núcleos septohipotalâmico, paraventricular, supramamilar nem na área pré-óptica (Tabela 2).

A Figura 7 ilustra a expressão de Fos (média \pm E.P.M., células $/ 0,1 \mathrm{~mm}^{2}$ ) em núcleos do diencéfalo, pertencentes à região do tálamo. Mostram-se a lâmina intergeniculada (bregma: -4,80), os núcleos suprageniculado (bregma: -6,04), 
peripeduncular (bregma: -6,04), paraventricular anterior (bregma: -1,30), e paraventricular posterior (bregma: -3,14). Para as cinco estruturas mostradas, cada grupo foi composto por um número de sujeitos correspondente a: $\mathrm{B}(\mathrm{N}=5-6), \mathrm{GC}(\mathrm{N}=$ 4-5), GE $(\mathrm{N}=5), \operatorname{LC}(\mathrm{N}=5-7)$ e LE $(\mathrm{N}=7)$. Observou-se, para todos as estruturas, uma tendência de aumento na expressão de Fos no claro. No entanto, o único aumento significativo de Fos registrou-se na lâmina intergeniculada (ver Tabela 2). A Anova não mostrou diferencias significativas no núcleo suprageniculado, peripeduncular, paraventricular anterior nem paraventricular posterior (Tabela 2).

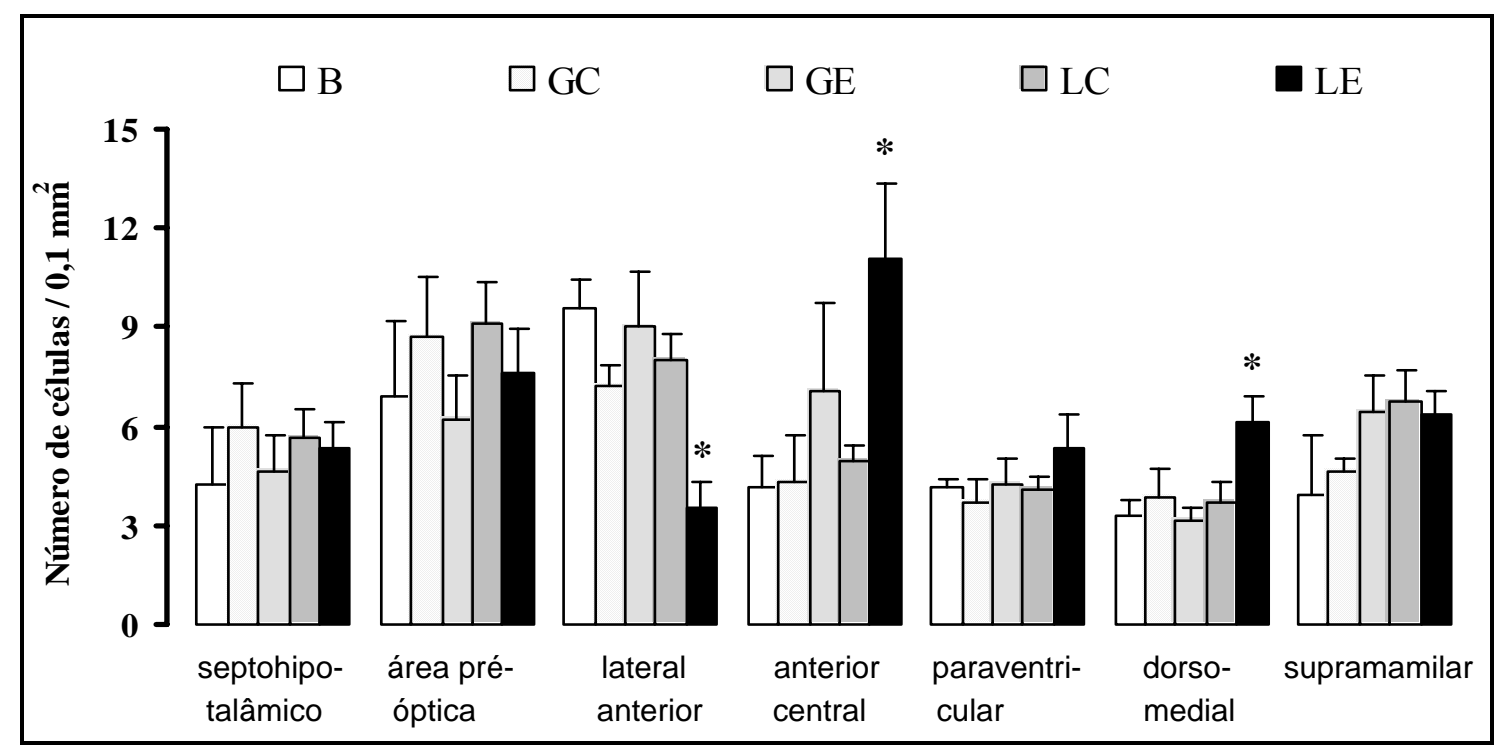

Figura 6. Expressão da proteína Fos no hipotálamo (células $/ 0,1 \mathrm{~mm}^{2}$, média \pm E.P.M.).

*, Diferente do grupo B (Dunnett, $p<0,05$ )

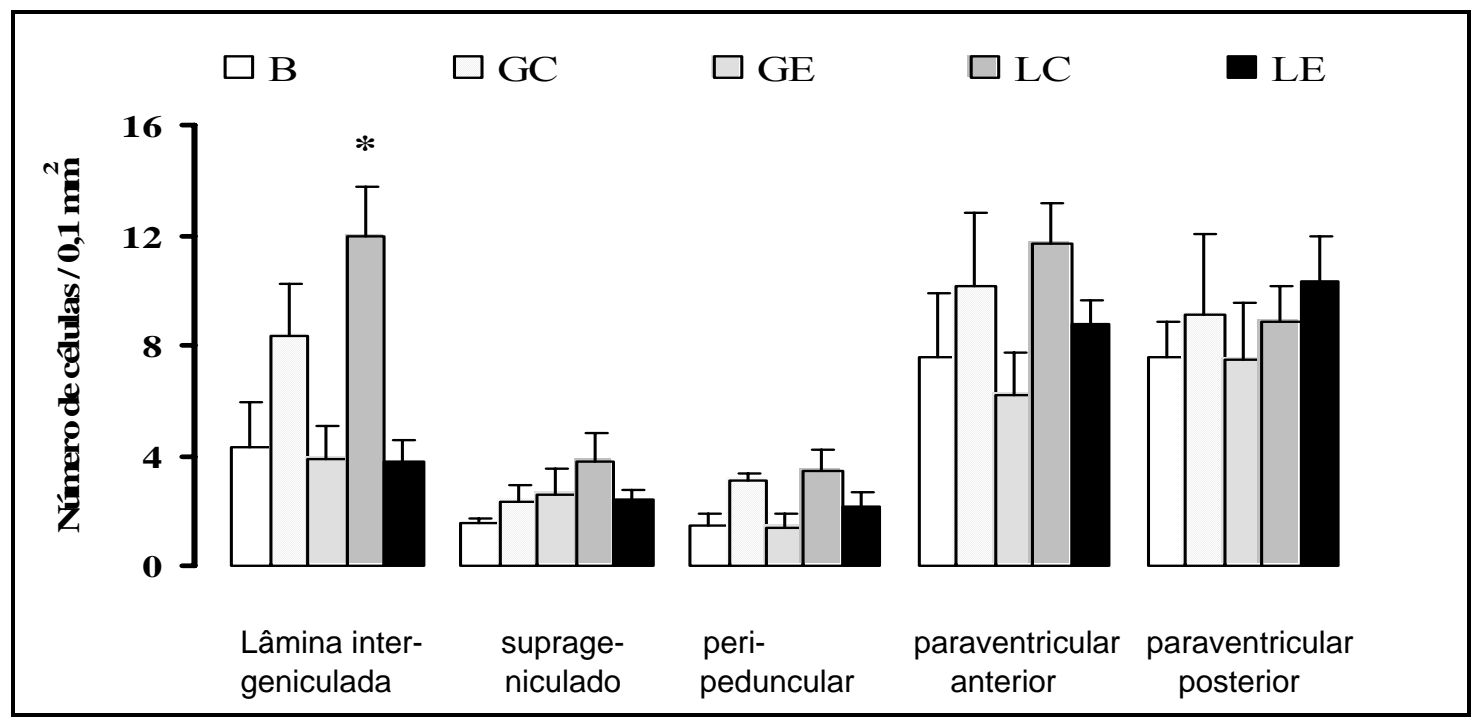

Figura 7. Expressão da proteína Fos no tálamo (média \pm E.P.M., células/0,1 mm²).

*, Diferente do grupo B (Dunnett, $p<0,05$ ) 
A Figura 8 ilustra a expressão de Fos (células/ $0,1 \mathrm{~mm}^{2}$, média \pm E.P.M.) em núcleos do tronco cerebral, pertencentes à região do mesencéfalo. Mostram-se ás áreas das camadas superficiais e camadas profundas do colículo superior (bregma: -6,04), pré-tectal olivar (bregma: -4,80) e os núcleos mediano e dorsal da rafe (bregma: -8,00). Para as cinco estruturas mostradas, cada grupo foi composto por um número de sujeitos correspondente a: B $(\mathrm{N}=4-5), \mathrm{GC}(\mathrm{N}=4), \mathrm{GE}(\mathrm{N}=4-6), \mathrm{LC}(\mathrm{N}=5-6)$ e LE $(\mathrm{N}=5$ 7).Os animais do grupo LE mostraram uma tendência de aumento na marcação de Fos no colículo superior mas não foi significativa (ver Tabela 2). Os ratos do grupo LC exibiram aumento significativo da expressão de Fos na área pré-tectal olivar, más o teste de Dunnett não acusou diferença com o grupo B, provavelmente pelo alto valor do E.P.M. da média do grupo B. Os animais do grupo LE exibiram aumento significativo de Fos no núcleo mediano da Rafe, mas não no núcleo dorsal (Tabela 2).

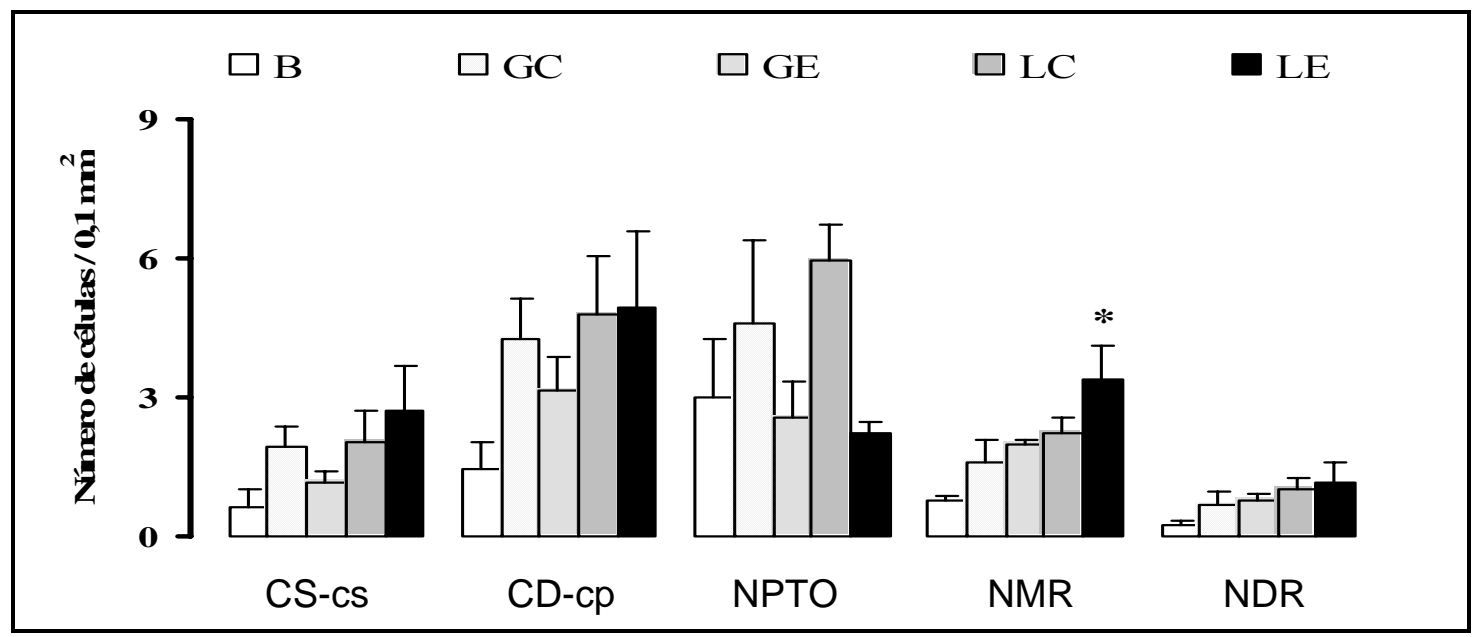

Figura 8. Expressão da proteína Fos no tronco cerebral (células $/ 0,1 \mathrm{~mm}^{2}$, média \pm E.P.M.) no Tronco cerebral

CS-cs, Colículo superior, camadas superficiais; CS-cp, colículo superior, camadas profundas; NPTO, núcleo pré-tectal olivar; NMR, núcleo mediano da rafe; NDR, núcleo dorsal da rafe. *, diferente do grupo biotério (Dunnett, $p<0,05$ )

A Figura 9 ilustra a expressão de Fos (células $/ 0,1 \mathrm{~mm}^{2}$, média \pm E.P.M.) em núcleos do tronco cerebral. Mostram-se ás áreas pertencentes ao locus coeruleus (bregma:-9,68) e à porção rostral da substância cinzenta periaqüedutal dorsomedial, dorsolateral e lateral (bregma: -6,04). A substância cinzenta periaquedutal teve um número de sujeitos correspondente a: $\mathrm{B}(\mathrm{N}=4-5), \mathrm{GC}(\mathrm{N}=5), \mathrm{GE}, \mathrm{LC}$, e $\mathrm{LE}(\mathrm{N}=6)$. Apesar do baixo número de sujeitos para a estrutura locus coeruleos: $\mathrm{B}$ e $\mathrm{GC}(\mathrm{N}=3)$, GE $(\mathrm{N}=5), \mathrm{LC}(\mathrm{N}=4)$ e LE $(\mathrm{N}=6)$, não se observaram grandes desvios da média. Os ratos do grupo LE exibiram um aumento significativo na expressão de Fos nesse núcleo 
(ver Tabela 2). Os animais do grupo LC mostraram uma tendência de aumento na expressão de Fos na substância cinzenta periaquedutal dorsomedial e dorsolateral, mas não foi significativa. Já na substância cinzenta periaquedutal lateral, nota-se um aumento na expressão de Fos nos animais do grupo LE, que não foi significativo quando comparado com os animais do grupo B (Tabela 2).

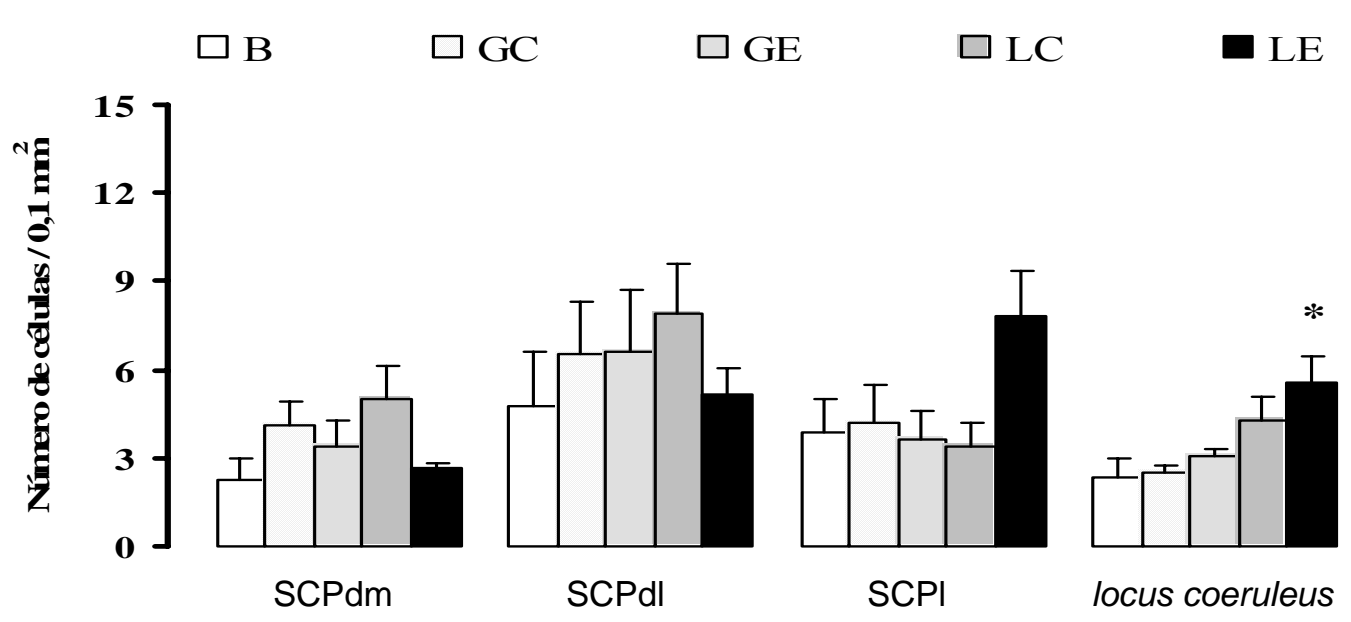

Figura 9. Expressão da proteína Fos no tronco cerebral (células/0,1 mm2, média \pm E.P.M.).

SCPdm, Substância cinzenta periaquedutal dorsomedial; SCPdl, substância cinzenta periaquedutal dorsolateral; SCPI, substância cinzenta periaquedutal lateral. *, diferente do grupo biotério (Dunnett, $\mathrm{p}$ $<0,05)$

A Tabela 3 mostra os resultados da análise de variância de duas vias da expressão da proteína Fos (células/0,1 mm², média \pm E.P.M.) em diferentes regiões do cérebro de ratos expostos a uma gaiola-viveiro ou ao labirinto em cruz elevado na presença e ausência de iluminação. As estruturas submetidas à analise de variância de duas vias foram aquelas nas que detectaram-se quaisquer diferenças com os dados do grupo que permaneceu no biotério, acusadas pelo teste de post hoc de Dunnett. A Anova de duas vias contou com a iluminação como um dos fatores (dois níveis: claro e escuro) e ambiente como o outro (dois níveis: gaiola e labirinto). Neste segundo caso, utilizou-se o teste post hoc de Student-Newman-Keuls, para comparações múltiplas de médias de grupos. Os valores de $\mathrm{P}$ iguais ou inferiores a 0,05 foram considerados significativos.

Os resultados desse procedimento mostraram que dos catorze núcleos analisados, doze núcleos tiveram diferenças significativas em algum dos fatores ou na interação deles. Os núcleo mediano da Rafe e o córtex pré-límbico não mostraram diferença alguma nos fatores nem na interação (Tabela 3). As diferenças significativas no fator ambiente e no fator iluminação correspondem principalmente às estruturas do telencéfalo. 
Tabela 3. Expressão da proteína Fos (células $/ 0,1 \mathrm{~mm}^{2}$, média \pm E.P.M.) em diferentes regiões do cérebro de ratos expostos a uma gaiola-viveiro ou ao labirinto em cruz elevado na presença e ausência de iluminação e resultados da análise de variância de duas vias.

G, Gaiola; L, labirinto em cruz elevado; C, claro; E, escuro; g. I., graus de liberdade; F, valores estatísticos da Anova; P, probabilidade.

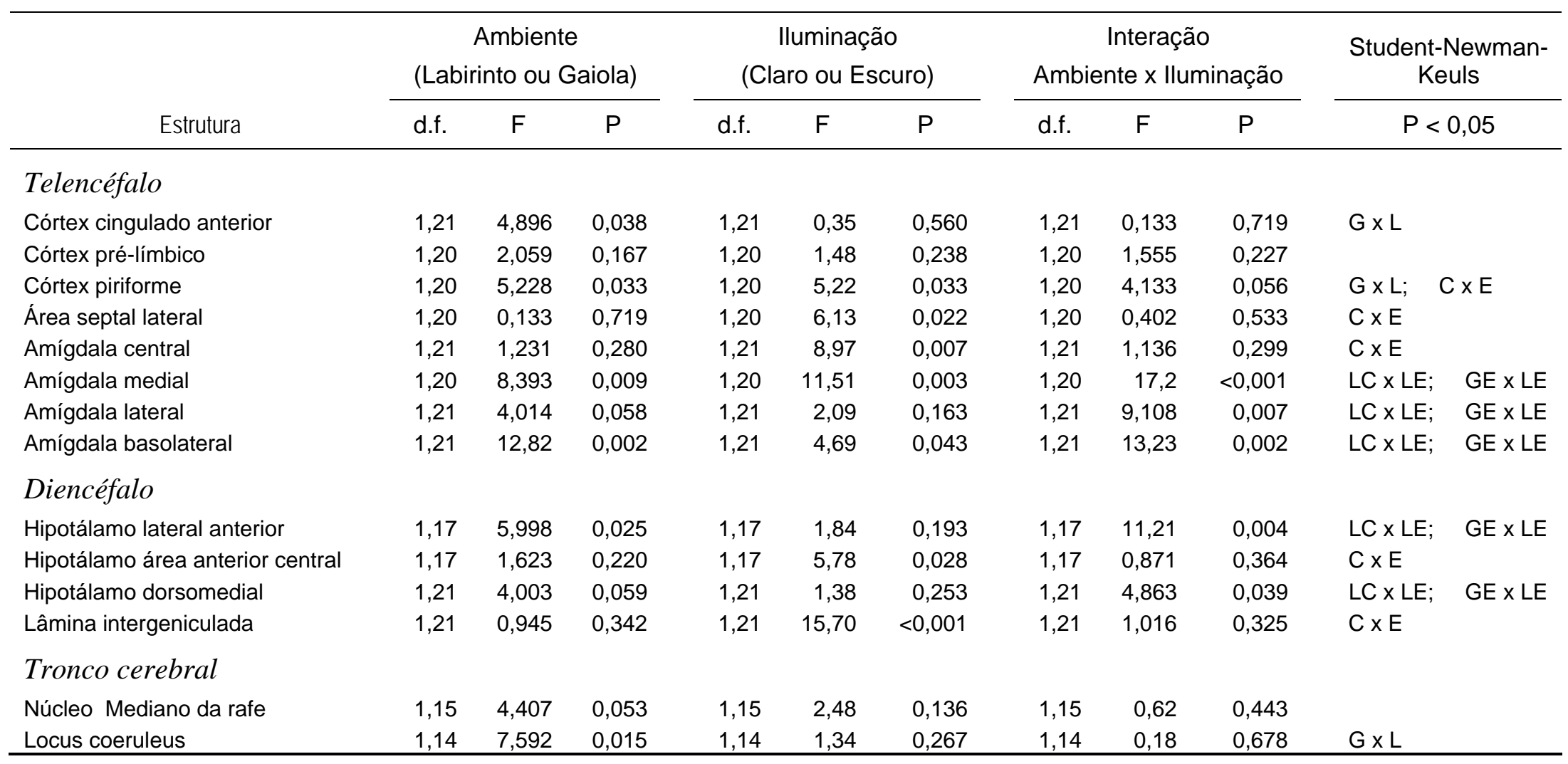


O córtex cingulado anterior e o locus coeruleus mostraram diferenças significativas exclusivamente no fator ambiente (ver Tabela 3). A lâmina intergeniculada, a área anterior do hipotálamo parte central, a área septal lateral e a amígdala central mostraram diferenças significativas unicamente no fator iluminação. $O$ córtex piriforme mostrou diferenças nos dois fatores, ambiente e iluminação, mas não na interação dos mesmos (Tabela 3). Os resultados da Anova de dois fatores permitiram diferenciar o padrão de ativação da amígdala nos grupo LE, que parecia semelhante com a analise de uma via. Os núcleos da amígdala basolateral e medial mostram diferenças significativas nos dois fatores e na interação dos mesmos. A amígdala central mostra diferenças exclusivas para o fator iluminação. A amígdala lateral não mostra diferenças nos dois fatores, mas apresenta diferença significativa na interação dos fatores (Tabela 3).

A Figura 10 representa o padrão de resultados da anova de dois fatores mostrando diferenças significativas, na interação dos fatores ambiente e iluminação. As diferenças significativas na interação dos fatores ambiente (gaiola e labirinto em cruz elevado) e Iluminação (claro e escuro) mostra que existe um aumento da marcação de Fos nos núcleos basolateral, lateral e medial da amígdala e no núcleo dorsomedial do hipotálamo quando os animais foram testados no LE comparados com o LC, no entanto essa diferença foi produzida pelo modelo e não pela iluminação.

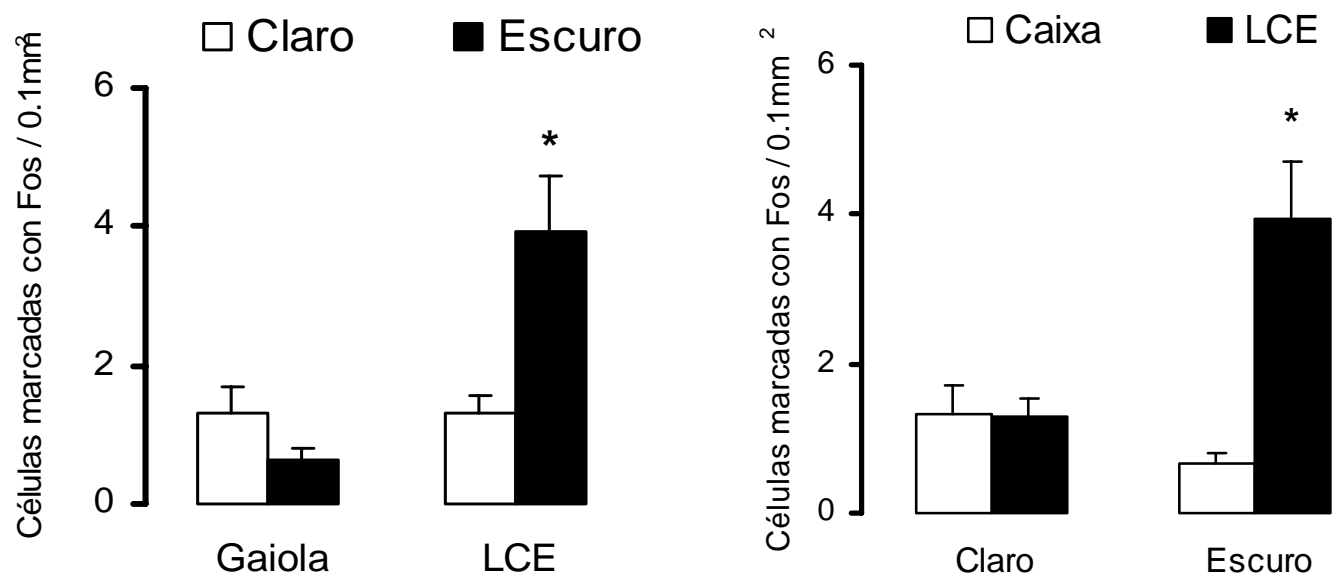

Figura 10. Padrão de Resultados da Anova de dois fatores mostrando diferenças significativas, na interação dos fatores ambiente (gaiola e labirinto em cruz elevado, LCE) e lluminação (claro e escuro), em núcleos do hipotálamo e da amígdala.

A Tabela 4 mostra os coeficientes de correlações de Spearman entre número de neurônios marcados por Fos e medidas comportamentais no labirinto em cruz elevado. 
A Figura 11 ilustra, por exemplo, o padrão de correlações entre a exploração dos braços abertos e a expressão de Fos no telencéfalo de animais testados no LCE, no claro e no escuro. Os comportamentos exibidos pelos animais testados no escuro, de aumento na exploração do braço aberto, nomeados porcentagem de entradas, número de entradas nas extremidades, tempo de permanência nos braços e nas extremidades, correlacionaram significativamente com aumento na expressão de Fos no córtex piriforme, amígdala central, hipotálamo dorsomedial e amígdala basolateral (ver Tabela 4). O teste de Sperman mostrou correlações negativas significativas entre o aumento da exploração dos braços fechados e a diminuição da marcação de Fos na amígdala central e colículo superior, quando os animais foram testados no escuro (Tabela 4).

Tabela 4. Coeficientes de correlações de Spearman entre o número de neurônios marcados por Fos (células $/ 0,1 \mathrm{~mm} 2$, média \pm E.P.M.) e medidas comportamentais no labirinto em cruz elevado.

\begin{tabular}{|c|c|c|c|c|c|c|}
\hline & \multicolumn{3}{|c|}{ Claro } & \multicolumn{3}{|c|}{ Escuro } \\
\hline & Coef. & $\mathrm{P}$ & $\mathrm{N}$ & Coef. & $P$ & $\mathrm{~N}$ \\
\hline \multicolumn{7}{|c|}{ Córtex piriforme } \\
\hline $\begin{array}{l}\text { Freqüência de entradas nos braços abertos } \\
\text { Tempo gasto nos braços abertos (s) } \\
\text { Tempo gasto nas extremidades dos braços abertos (s) }\end{array}$ & $\begin{array}{l}-0,815 \\
-0,750 \\
-0,811\end{array}$ & $\begin{array}{l}0,015 \\
0,038 \\
0,015\end{array}$ & $\begin{array}{l}7 \\
7 \\
7\end{array}$ & $\begin{array}{l}0,436 \\
0,786 \\
0,821\end{array}$ & $\begin{array}{l}0,297 \\
0,025 \\
0,015\end{array}$ & $\begin{array}{l}7 \\
7 \\
7\end{array}$ \\
\hline \multicolumn{7}{|c|}{ Amígdala central } \\
\hline $\begin{array}{l}\text { Porcentagem de entradas nos braços abertos } \\
\text { Freqüência de entradas nos braços fechados } \\
\text { Distância percorrida nos braços fechados (m) }\end{array}$ & $\begin{array}{c}-0,333 \\
0,324 \\
0,128\end{array}$ & $\begin{array}{l}0,438 \\
0,438 \\
0,720\end{array}$ & $\begin{array}{l}7 \\
7 \\
7\end{array}$ & $\begin{array}{l}0,919 \\
-0,908 \\
-0,865\end{array}$ & $\begin{array}{l}0,000 \\
0,000 \\
0,006\end{array}$ & $\begin{array}{l}7 \\
7 \\
7\end{array}$ \\
\hline \multicolumn{7}{|c|}{ Amígdala basolateteral } \\
\hline $\begin{array}{l}\text { Tempo gasto nos braços abertos (s) } \\
\text { Tempo gasto nas extremidades dos braços abertos (s) }\end{array}$ & $\begin{array}{l}0,128 \\
-0,360\end{array}$ & $\begin{array}{l}0,720 \\
0,388\end{array}$ & $\begin{array}{l}7 \\
7\end{array}$ & $\begin{array}{l}0,775 \\
0,847\end{array}$ & $\begin{array}{l}0,025 \\
0,006\end{array}$ & $\begin{array}{l}6 \\
6\end{array}$ \\
\hline \multicolumn{7}{|c|}{ Hipotálamo dorsomedial } \\
\hline Porcentagem de entradas nos braços abertos & 0,221 & 0,658 & 6 & 0,750 & 0,038 & 7 \\
\hline \multicolumn{7}{|c|}{ Hipotálamo lateral anterior } \\
\hline $\begin{array}{l}\text { Porcentagem de entradas nos braços abertos } \\
\text { Tempo gasto nos braços abertos (s) }\end{array}$ & $\begin{array}{l}-0,868 \\
-0,638\end{array}$ & $\begin{array}{l}0,033 \\
0,175\end{array}$ & $\begin{array}{l}6 \\
6\end{array}$ & $\begin{array}{l}-0,638 \\
-0,841\end{array}$ & $\begin{array}{l}0,175 \\
0,033\end{array}$ & $\begin{array}{l}6 \\
6\end{array}$ \\
\hline \multicolumn{7}{|c|}{ Camadas profundas do colículo superior } \\
\hline $\begin{array}{l}\text { Freqüência de entradas nos braços fechados } \\
\text { Distância percorrida nos braços fechados (m) } \\
\text { Porcentagem de entradas nos braços abertos }\end{array}$ & $\begin{array}{c}0,051 \\
0,000 \\
-0,103\end{array}$ & $\begin{array}{l}0,950 \\
1,000 \\
0,783\end{array}$ & $\begin{array}{l}5 \\
5 \\
5\end{array}$ & $\begin{array}{c}-0,927 \\
-0,893 \\
0,857\end{array}$ & $\begin{array}{l}0,000 \\
0,000 \\
0,006\end{array}$ & $\begin{array}{l}7 \\
7 \\
7\end{array}$ \\
\hline \multicolumn{7}{|c|}{ Camadas superficiais do colículo superior } \\
\hline Distância percorrida nos braços fechados (m) & $-0,921$ & 0,017 & 5 & $-0,821$ & 0,015 & 7 \\
\hline \multicolumn{7}{|c|}{ Núcleo mediano da rafe } \\
\hline Distância percorrida nos braços fechados (m) & 0,103 & 0,783 & 5 & 0,782 & 0,025 & 7 \\
\hline
\end{tabular}




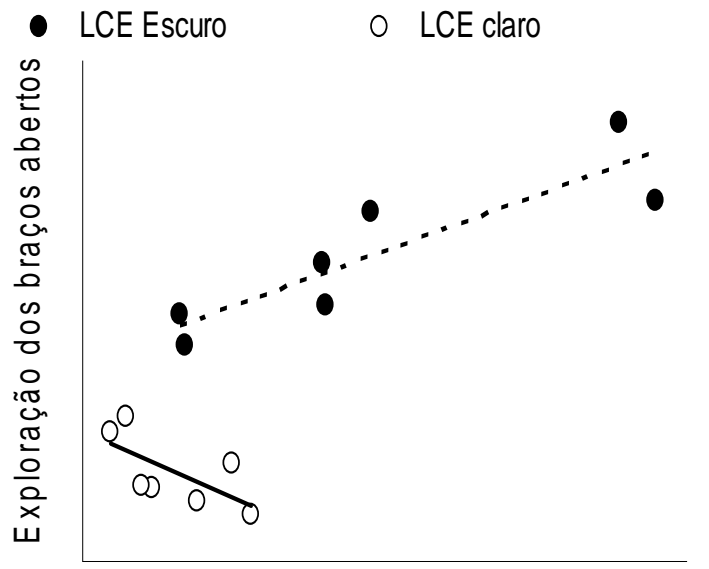

Expressão de Fos (neurônios / 0,1mm2)
Figura 11. Padrão de correlações entre a exploração dos braços abertos e a expressão de Fos em estruturas do telencéfalo de animais testados no LCE, no claro e no escuro. 


\section{Discussão}

No presente trabalho se investigou o efeito da presença ou ausência de iluminação sobre o comportamento de ratos testados no labirinto em cruz elevado. Além do uso do modelo de ansiedade e as medidas comportamentais nele registradas, utilizou-se uma técnica imunoistoquímica que permitiu marcar a proteína Fos no cérebro de ratos testados nas condições descritas de iluminação. A partir da comparação entre os grupos utilizados, analisaram-se outras condições, tanto do ambiente como do procedimento que alteraram a expressão de Fos. Assim, a comparação entre os animais que permaneceram no biotério e os animais expostos a uma gaiola-viveiro, ou ao labirinto em cruz elevado, no claro e no escuro, permitiu identificar estruturas sensíveis ao manuseio e transporte do animal por parte do experimentador e à exploração de novos ambientes. Desse conjunto de estruturas, uma segunda análise, mostrou algumas áreas relacionadas especificamente com respostas à iluminação, outras relacionadas com a exploração de ambiente novos, e finalmente, áreas subjacente à interação entre esses dois fatores, iluminação e exploração de ambientes. Adicionalmente, os coeficientes de correlação estabelecidos entre o número de neurônios marcados por Fos e medidas comportamentais no labirinto em cruz elevado, evidenciaram comportamentos específicos subjacente à ativação neuronal observada. Compararam-se também os resultados obtidos da expressão de Fos após exposição ao labirinto na presença de iluminação com os estudos prévios.

\section{Comportamento no labirinto em cruz elevado}

Os resultados comportamentais mostraram que os ratos testados no labirinto no escuro exibem um aumento na porcentagem de entradas e tempo de permanência nos braços abertos, assim como de entradas e tempo nas extremidades abertas. No entanto, as medidas registradas nos braços fechados, número de entradas e distância percorrida, não mostraram diferenças significativas nos dois grupos. Esses resultados indicam que o aumento ou a diminuição da exploração dos braços abertos, no escuro e no claro respectivamente, não depende do aumento ou a diminuição geral da locomoção. García e cols. (2005; 2006, manuscrito em preparação) observaram os mesmos efeitos da iluminação sobre o comportamento de animais testados no escuro. $\mathrm{O}$ aumento da locomoção em animais noturnos, produzida por iluminações tênues, ou mesmo a escuridão é um fenômeno discutidos em outros trabalhos como mascaragem positiva 
(Mrosovsky, 1999; Redlin e Mrosvsky, 1999; Morin e Allen, 2005). Nesses estudos, utilizam-se rodas de atividade para o registro comportamental. Essa resposta comportamental é observada em outros testes. King e Jones (2001) relataram que níveis altos de luminosidade não alteram o comportamento de ratos no campo aberto, na tábua de buracos e nem no labirinto instável, mas quando o teste é realizado no escuro, observa-se um aumento na atividade locomotora. Apesar das diferenças entre o labirinto em cruz elevado e outros teste utilizados para medidas de exploração e locomoção, poderia sugerir-se que a mascaragem positiva induzida na ausência de luz, observada em outros teste, seria uma conseqüência da redução da aversão gerada pelo ambiente iluminado. Desse ponto de vista, o labirinto em cruz elevado no escuro, torna-se uma ferramenta útil no estudo dos efeitos da iluminação sobre o comportamento, já que abrange tanto o fator e ansiedade como o fator locomoção (Cruz e cols., 1994; Rodgers e Johnson, 1995).

\section{Expressão da proteína Fos}

\section{Exposição ao labirinto em cruz elevado: comparação com os estudos prévios.}

A expressão de Fos em ratos testados no labirinto em ambientes iluminados foi estudada anteriormente por Silveira e cols. (1993), por Duncan e cols. (1996) e recentemente por Beijamini e Guimarães (2006). Neste trabalho, a exposição de animais ao labirinto em cruz elevado no claro (30 lux), aumentou a expressão de Fos na área septal lateral, hipotálamo lateral anterior, lâmina intergeniculada e no córtex préfrontal medial, quando comparado com um grupo biotério. $\mathrm{O}$ aumento de Fos no hipotálamo lateral anterior foi observado por Silveira e cols. (1993) e no córtex préfrontal medial por Duncan e cols. (1996). Porém, no presente estudo não se observou incremento significativo na expressão de Fos em núcleos da amígdala e da substância cinzenta periaqüedutal, envolvidas no sistema de defesa, como foi observado por os autores mencionados. No entanto, Beijamini e Guimarães (2006) tampouco encontraram aumento na expressão de Fos nesses núcleos, após exposição ao labirinto em um ambiente iluminado.

Alguns fatores na metodologia dos trabalho podem explicar as diferenças nos resultados. O critério de Silveira e cols.(1993) para classificar como significativa a marcação de Fos de uma estrutura, consistia em um número de células superior a 5 por $0,01 \mathrm{~mm}^{2}$ de área. Independentemente do número de células por estrutura, o critério (do presente trabalho para determinar a significância do aumento de Fos em uma estrutura 
dependeu da analise de variância e do teste de post hoc de Dunnett, quando comparadas as médias do grupo labirinto no claro com os animais do grupo biotério. Outro fator na metodologia pode se atribuir ao tempo de exposição ao labirinto. Hinks e cols. (1996) relataram que 30 minutos de exposição ao labirinto aumenta de forma geral a expressão de RNAm de c-fos, comparado aos 5 minutos habituais do procedimento. Nos estudos de Silveira e cols. (1993) e Beijamini e Guimarães (2006), os ratos foram expostos durante 15 minutos ao teste, enquanto que no estudo de Duncan e cols. (1996) e no presente estudo, os ratos foram expostos durante 5 minutos. A diferença mais importante na metodologia dos estudos mencionados corresponde a linhagem de ratos utilizados. Enquanto Silveira e cols. (1993) e Duncan e cols. (1996) utilizaram animais Long-Evans e Sprague-Dawley respectivamente, Beijamini e Guimarães (2006) utilizaram ratos Wistar, a mesma linhagem utilizada neste estudo. Alguns trabalhos mostram que o comportamento de ratos de diferentes linhagens não é semelhante no labirinto em cruz elevado (Brett e Pratt, 1989; Schmitt e Hiemke, 1998). Interpretados em conjunto, os dados apresentados indicam que a linhagem de ratos, e não o tempo de exposição ao labirinto, produziria padrões diferenciado na expressão de Fos nos núcleos da amígdala.

Contrário ao esperado, animais testados no labirinto em cruz elevado no escuro, exibiram aumentos significativos na expressão de Fos, nos núcleos da amígdala lateral, basolateral e medial, núcleos do hipotálamo lateral anterior e dorsomedial, quando comparados com os animais testados no mesmo modelo na presença de luz. Levando em consideração a ausência de estudos neste assunto, a interpretação dos dados requer algumas considerações fundamentais. Em primeiro lugar, não é possível partir do fato de que o labirinto no escuro conserve as características de um modelo de ansiedade. Nenhum estudo tem validado o modelo em ambientes sem iluminação. Além disso, as drogas gabaérgicas parecem perder seu efeito comportamental quando os ratos são testados no escuro (García e cols. 2006, manuscrito em preparação). Em segundo lugar, é importante lembrar que no cérebro, uma mesma estrutura relaciona-se com diferentes comportamentos. Embora a função da amígdala associe-se quase sempre com o medo condicionado, alguns estudos evidenciam o papel da amígdala no processamento de incentivos (Wang e cols., 2005; Balleine, 2005; Balleine e Killcross, 2006). A partir dessas considerações, interpretam-se os resultados da expressão de Fos no labirinto, em ambas condições de iluminação como a exposição do animal a um ambiente novo. 


\section{Exposição a ambientes familiares e novos.}

Os animais que permaneceram no biotério exibiram pouca expressão de Fos na maioria das estruturas analisadas. Os resultados obtidos confirmaram que os níveis basais de expressão de Fos são muito baixos (Herrera e Robertson, 1996). No entanto, altos níveis foram observados na área pré-óptica e no núcleo lateral anterior do hipotálamo. Esse nível basal elevado de Fos possivelmente responda, entre outra funções, à inibição de sistemas de ativação envolvidos na regulação do sono (McGintye cols.,2004) ou à modulação de sinais hormonais no cérebro (Charlier e Balthazart, 2005).

Os resultados da primeira análise de variância indicam que, exceto no córtex cingulado anterior, o manuseio, transporte e exposição a um ambiente familiar não produz aumento significativo de Fos na maioria das estruturas analisadas. Os animais expostos a um ambiente familiar (gaiola-viveiro), não aumentaram significativamente a expressão de Fos, comparados com os níveis basais exibidos pelos animais do grupo biotério. Sabe-se que a intensidade do manuseio, acompanhado de outros procedimentos, altera a expressão de c-fos RNAm no cérebro de ratos (Asanuma e cols., 1992). Os animais expostos a um ambiente novo (labirinto em cruz elevado), mostraram aumento significativo na expressão de Fos em quase a metade das estruturas analisadas. Diversos estudos mostram que a novidade aumenta a expressão de Fos e cfos RNAm, no sistema nervoso central (Handa e cols., 1993; Papa e cols., 1993; Koh, e cols. 2003; Jenkins e cols., 2004). Um resultado interessante foi o incremento significativo de Fos no córtex cingulado anterior, tanto no ambiente familiar como no ambiente novo. Os estudos indicam que a expressão de Fos no córtex cingulado, aumenta pela novidade (Handa e cols., 1993; Zhu e cols., 1995) e se reduz pela habituação (Struthers e cols., 2005)

Ratos testados no labirinto, independentemente da iluminação, exibiram aumento na expressão de Fos no córtex cingulado, piriforme e locus coeruleus. Essas estruturas participam no comportamento de exploração de ambientes novos (Sara e cols., 1994; Kitchigina e cols., 1997; Stone e cols., 2006) exibindo incremento dos níveis de noradrenalina (Pudovkina e cols., 2001; Stone e cols., 2006). A atividade dos receptores $\alpha_{1}$-adrenérgicos é fundamental para a ativação comportamental e motora e possivelmente ativam uma hierarquia de estruturas que controlam comportamentos motivados (Stone e cols., 2006). A maior quantidade de neurônios que expressaram Fos observou-se no córtex piriforme dos animais do grupo LE. A informação olfativa é a única informação que tem acesso direto à amígdala sem passar pelo tálamo e 
desempenha um papel importante em vários aspectos do comportamento de mamíferos, incluindo localização de alimentos (Mennella e Beauchamp, 2002) e regulação de estados emocionais (Otto e cols., 2000). Wilson e Stevenson (2003) concluem que todos os odores são inicialmente codificados como objetos no córtex piriforme. Schwabe e cols. (2004) descreveram projeções do córtex piriforme para estruturas do sistema límbico. Além do fator ambiente, o córtex piriforme mostra diferenças no fator iluminação. No escuro, poderiam se ativar diversas estruturas cerebrais que processariam outras fonte de informação sensorial.

Levando em consideração o aumento significativo na expressão de Fos tanto no córtex piriforme quanto na amígdala, em ratos testados no escuro, infere-se que em ambientes sem iluminação a informação olfativa adquiriria um valor emocional importante no comportamento exploratório.

\section{Exposição a ambientes iluminados e escuros.}

De forma geral os dados confirmaram que a luminosidade induz a expressão de Fos em diferentes núcleos do cérebro (Correa-Lacarcel, 2000; Prichard e cols., 2002; Greferath e cols., 2004). A lâmina intergeniculada, a área septal lateral e o córtex préfrontal medial mostraram aumentos significativos de Fos no grupo de animais testados no LC. Além disso, a análise bifatorial mostrou diferenças significativas exclusivas no fator iluminação nas duas primeiras estruturas. No entanto, o córtex pré-frontal medial não parece relacionar-se com o fator iluminação. Vários estudos evidenciam a relação da área septal no medo e na ansiedade (Menard e Treit, 1999; Treit D. e Menard, 2000; Degroot e Treit, 2004, McNaughton e Corr, 2004). No entanto, alguns estudos relacionam essa estrutura com a regulação de fotoperíodos do sistema reprodutivo (Zamorskyi e Khodorovskyi, 1993; Slavetna e Khodorovskyi, 1994). A lâmina intergeniculada do tálamo foi descrita inicialmente por Hickey e Spear (1976) como uma região de neurônios localizados entre os núcleos dorsal e ventral do núcleo geniculado lateral e bilateralmente inervada pela retina. Possui conexões com o telencéfalo, diencéfalo e mesencéfalo, incluindo núcleos do pretectum. (Vrang e cols., 2003; Horowitz e cols., 2004 e Horowitz e cols., 2005). A informação luminosa, atinge o núcleo supraquiamático indiretamente através da lâmina intergeniculada e seu trato genículo-hipotalámico (Pickard, 1982). Assim, a lâmina intergeniculada participa na integração de informação luminosa e nas mudanças do ritmo circadiano produzidas por estímulos não luminosos, por exemplo, ativação comportamental induzida por rodas de atividade (Vrang e cols., 2003). Baixos níveis de luminosidade induzem expressão de 
Fos nos neurônio dessa estrutura (Muscat e Morin, 2006). Possivelmente, a detecção de luz pela lâmina intergeniculada module o sistema de inibição comportamental, envolvendo a área septal.

Animais testados no LE exibiram aumento significativo na expressão de Fos na amígdala central. Essa estrutura mostrou diferenças significativas no fator iluminação assim como as duas estruturas mencionadas anteriormente. Pode-se sugerir que, em ambientes escuros, a amígdala central poderia ter o mesmo valor que a lâmina intergeniculada em ambientes iluminados. Nenhum estudo do sistema visual descreve uma via direta da retina para a amígdala que explique o aumento de Fos nessa estrutura pela estimulação visual. No entanto, os trabalhos de Linke e cols. (1999; 2000) descrevem conexões colículo superior - tálamo - amígdala que explicariam um possível substrato para esta via.

Outras estruturas relacionadas com o sistema visual, como o colículo superior e área pretectal olivar não mostraram diferença com o grupo biotério na primeira análise. No entanto, se estabeleceram correlações entre os comportamentos no labirinto e o aumento de Fos nas camadas profundas do colículo superior. No LE, os animais que aumentam a porcentagem de entradas nos braços abertos, incrementam a marcação de Fos nessa região. Porém, Lu e cols. (2001) mostraram que animais mantidos no escuro exibem um incremento de Fos no colículo superior, e que essa expressão elevada pode se eliminar administrando tetrodotoxina no vítreo. Os autores sugerem que essa expressão é produzida por alterações na atividade da retina.

\section{Exposição ao labirinto em cruz elevado: interação entre iluminação e novidade do ambiente. \\ Os resultados da interação entre o fator ambiente e iluminação mostraram um} padrão de diferenças significativas para estruturas da amígdala e hipotálamo. Os animais testados no LE exibiram aumento significativo na expressão de Fos no núcleo basolateral, medial e lateral da amígdala e o núcleo dorsomedial do hipotálamo, comparados com os animais testados no LC e com os animais que permaneceram na GE. Dessa forma, infere-se que o aumento de Fos nessas estruturas, não foi um efeito direto da iluminação, como no caso da amígdala central e tampouco um efeito exclusivo do ambiente novo, como no caso do locus coeruleus e cingulado anterior. Esse grupo de estruturas exibem incremento de Fos pela interação dos dois fatores: Um ambiente novo e escuro. 
Os dados sugerem que os ambientes familiares, além de induzir pouca expressão de Fos, reduzem ademais os efeitos da presença ou ausência de luz. Caso contrário, a novidade do ambiente, intensifica o efeito da condição de iluminação. Os animais expostos ao (labirinto em cruz elevado), exibiriam de início uma ativação neural elevada, representada pela indução da expressão de Fos pela novidade. Os dados sugerem a participação do sistema noradrenérgico na ativação inicial produzida pela ambiente novo. Esse sistema estaria regulado pelas fontes de informação sensorial. No claro, a luz permitiria a formação de imagens e o reconhecimento de locais novos ou familiares. No caso do labirinto, a novidade do local é inerente a uma situação de conflito, que gera a inibição do comportamento (Pellow e cols., 1985; Cruz e cols., 1994; Rodgers e Cole, 1994) e provavelmente diminuição da expressão de Fos em neurônios noradrenérgicos.

No escuro, outras fontes sensoriais de informação podem ganhar relevância para o animal sobre o sistema visual. Esse processo integraria o sistema olfativo e o sistema de ativação inicial induzido pela novidade, e seriam modulados pelo córtex piriforme, locus coeruleus e o córtex cingulado. Os núcleos da amígdala regulariam o processo de atenção aos estímulos novos (Rasia-Filho e cols. 2000; Pitkanen e cols., 2000; Baxter e Murray, 2002) e fornecimento do valor emocional desses estímulos (Wang e cols., 2005; Balleine e Killcross, 2006), levando em consideração que a escuridão pode representar um ambiente menos aversivo para um animal noturno. 


\section{Referências Bibliográficas}

Andre, V., Pineau, N., Motte, J.E., Marescaux, C., Nehlig, A. (1998) Mapping of neuronal networks underlying generalized seizures induced by increasing doses of pentylenetetrazol in the immature and adult rat: a Fos immunohistochemical study. European Journal of Neuroscience, 10(6):2094-106.

Anseloni, V. Z. e Brandão, M. L. (1997). Ethopharmacological analysis of behavior of rats using variations of the elevated plus-maze. Behavioural Pharmacology, 8: 533-540.

Asanuma, M., Ogawa, N., Hirata, H.,Chou, H., Tanaka, K., Mori, A. (1992) Opposite effects of rough and gentle handling with repeated saline administration on c-fos mRNA expression in the rat brain. Journal of Neural Transmission, 90, (3):163-169.

Aschoff J. (1960) Exogenous and endogenous components in circadian rhythms, Cold Spring Harbor symposia on quantitative biology 25: 11-28.

Balleine, B.W. (2005) Neural bases of food-seeking: affect, arousal and reward in corticostriatolimbic circuits Physiology and behavior, 86(5):717-30.

Balleine, B.W. e Killcross, S. (2006) Parallel incentive processing: an integrated view of amygdala function. Trends in neurosciences, 29(5):272-9.

Barron, S., Serratosa, J., Tusell, J.M. (1995) Regulation of c-fos expression by convulsants and hexachlorocyclohexane isomers in primary cultures of cortical neurons. Journal of neurochemistry, 64(4):1708-14.

Baxter, M.G. e Murray E.A. (2002) The amygdala and reward. Nature reviews. Neuroscience. 3(7):563-73.

Beck, C. H. e Fibiger, H. C. (1995). Conditioned fear-induced changes in behavior and in the expression of the immediate early gene Fos: With and without diazepam pretreatment. Journal of Neuroscience, 15: 709-720.

Becker, A. e Grecksch, G. (1996). Illumination has no effect on rats' behavior in the elevated plus-maze. Physiology and behavior, 59(6): 175-177.

Beijamini, V. e Guimaraes, F.S. (2006) Activation of neurons containing the enzyme nitric oxide synthase following exposure to an elevated plus maze. Brain research bulletin, 69(4):347-55.

Brandão, M. L., Troncoso, A. C., Silva, M. A. e Huston, J. P. (2003) The relevance of neuronal substrates of defense in the midbrain tectum to anxiety and stress: empirical and conceptual considerations. European Journal of Pharmacology, 463: 225-233.

Brett, R.R. e Pratt, J.A. (1989) Limitations of the elevated plus-maze test for assessing the effects of chronic benzodiazepine administration, British Journal of pharmacology, 96: 313.

Cardenas, F., Lamprea, M. R. e Morato, S. (2001). Vibrissal sense is not the main sensory modality in the rat exploratory behavior in the elevated plus-maze. Behavioural Brain Research, 122: 169-174.

Charlier, T.D. e Balthazart, J. (2005) Modulation of hormonal signaling in the brain by steroid receptor coactivators. Reviews in the neurosciences, 16(4):339-57.

Correa-Lacarcel, J., Pujante, M.J., Terol, F.F., Almenar-Garcia,V., Puchades-Orts, A., Ballesta, J.J., Lloret, J., Robles, R.A., Sanchez-del-Campo, F. Stimulus frequency affects c-Fos expression in the rat visual system. Journal of Chemical Neuroanatomy, 18: 135- 146.

Crompton, A.W., Taylor, C.R., e Jagger, J.A.(1978) Evolution of homeothermy in mammals. Nature 272:333-336.

Cruz, A.P.M., Frei, F. e Graeff, F. G. (1994). Ethopharmacological analysis of rat behavior on the elevated plus-maze. Pharmacology Biochemistry and Behavior, 49: 171-176.

Daly, M., Behrends, P.R., Wilson, M.I. (2000) Activity Patterns of Kangaroo Rats - Granivores in a Desert Habitat. In Activity Patterns in Small Mammals; Halle, S., Stenseth, N., Eds.; Springer-Verlag: Berlin; 145-158.

Degroot, A. e Treit, D. (2004) Anxiety is functionally segregated within the septo-hippocampal system. Brain Research. 1001(1-2):60-71. 
Duncan, G. E., Knapp, D. J. e Breese, G. R. (1996). Neuroanatomical characterization of Fos induction in rat behavioral models of anxiety. Brain Research, 713: 79-91.

Edelstein, K. e Mrosovsky, N. (2001) Behavioral responses to light in mice with dorsal lateral geniculate lesions. Brain Research, 918: 107-112

Erkert, H.G. (1974) Der Einfluss des Mondlichtes auf die Aktivitätsperiodik nachtaktiver Säugetiere. Oecologia Berlin, 14: 269-287.

Erkert, H.G. e Gröber, J. (1986) Direct Modulation of Activity and Body Temperature of Owl Monkeys (Aotis lemurensis griseimembra) by Low Light Intensities. Folia primatologica, 47: 171-188.

García, A. M. B, Cardenas, F. e Morato S. (2006). Do gabaergic drugs lose their behavioral effects when rats are tested in the dark? (Manuscrito em preparação).

García, A.M.B., Cardenas, F. e Morato S. (2005). Effect of Different Illumination Levels on Rat Behavior in the Elevated Plus-Maze. Physiology and Behavior, 8: 265-270.

Gentsch, C., Lichtsteiner, M., Kraeuchi, K. e Feer, H. (1982). Different reaction patterns in individually and socially reared rats during exposures to novel environments. Behavioural Brain Research, 4: 45-54.

Gray, J.A. e McNaughton, N. (2000) The Neuropsychology of anxiety: an enquiry into the functions of the septo-hippocampal system (2nd ed.), Oxford University Press, Oxford.

Greferath, U. Nag, N., Zele, A.J., Bui, B.V., Wilson, Y., Vingrys, A.J. e Murphy, M. (2004) Fos-tau-LacZ mice expose light-activated pathways in the visual system. Neuroimage, 23(3):1027-38.

Griebel, G., Moreau, J.L., Jenck, F., Martin, J. R. e Misslin, R. (1993). Some critical determinants of the behaviour of rats in the elevated plus-maze. Behavioural Processes, 29: $37-48$.

Handa, R.J., Nunley, K.M. e Bollnow, M.R. (1993) Induction of c-fos mRNA in the brain and anterior pituitary gland by a novel environment. Neuroreport, 4: 1079-1082.

Handley, S. L. e Mithani, S. (1984). Effects of alpha-adrenoceptor agonists and antagonists in a maze-exploration model of 'fear'-motivated behaviour. Naunyn-Schmiedeberg's Archives of Pharmacology, 327: 1-5.

Harris, J.A. (1998) Using Fos as a neural marker of pain. Brain Research Bulletin. 45(1):1-8.

Hattar, S., Lucas, R.J. Mrosovsky, N. Thompson, S. Douglas, R.H., Hankins, M.W. Lem, J., Biel, M., Hofmann, F., Foster, R.G. e Yau, K.W. (2003) Melanopsin and rod-cone photoreceptive systems account for all major accessory visual functions in mice, Nature 424: 76-81.

Herrera, D.G. e Robertson, H.A. (1996) Activation of c-fos in the brain. Progress in neurobiology, 50 (2-3):83-107.

Hickey, T.L. e Spear, P.D. (1976) Retinogeniculate projections in hooded and albino rats an autoradiographic study, Experimental brain research, 24: 523-529.

Hinks, G.L., Brown, P., Field, M., Poatand, J.A. e Hughes, J. (1996) The anxiolytics CI-988 and chlordiazepoxide fail to reduce immediate early gene mRNA stimulation following exposure to the rat elevated X-maze. European Journal of Pharmacology, 312 (2):153161.

Hoffman,G. e Lyo, D. (2002). Anatomical markers of activity in neuroendocrine systems: Are we all fos-ed out'?. Journal of Neuroendocrinology, 14: 259-268.

Hogg, S. (1996). A review of the validity and variability of the elevated plus-maze as an animal model of anxiety. Pharmacology Biochemistry and Behavior, 54: 21-30.

Horowitz, S.S. Blanchard, J.H. e Morin, L.P. (2004) Intergeniculate leaflet and ventral lateral geniculate nucleus afferent connections an anatomical substrate for functional input from the vestibulo-visuomotor system, The Journal of comparative neurology. 474: $227-245$.

Horowitz, S.S. Blanchard, J.H. e Morin, L.P. (2005) Medial vestibular connections with the hypocretin (orexin) system. The Journal of comparative neurology, 487:127-146.

Jenkins, T. A., Amin, E., Pearce, J. M, Brown, M. W. e Aggleton, J. P. (2004) Novel spatial arrangements of familiar visual stimuli promote activity in the rat hippocampal formation but not the parahippocampal cortices: a c-fos expression study. Neuroscience, 124 (1): 43-52. 
Johnston, T.D. e Edwards, L. (2002) Genes, interactions, and the development of behavior. Psychological Review, 109:26-34.

King, S. M. e Jones, N. (2001). Influence of circadian phase and test illumination on pre-clinical models of anxiety. Physiology and Behavior, 72: 99-106.

Kitchigina, V., Vankov, A., Harley, C., Sara, S.J. (1997) Novelty-elicited, noradrenalinedependent enhancement of excitability in the dentate gyrus. The European journal of neuroscience. 9(1):41-7.

Koh, M.T., Wilkins, E.E., Bernstein, I.L. (2003) Novel Tastes Elevate c-fos Expression in the Central Amygdala and Insular Cortex: Implication for Taste Aversion Learning. Behavioral Neuroscience. 117(6):1416-1422.

Kovács, K. J. (1998). Fos as a transcription factor: A stressful (re)view from a functional map. Neurochemistry International, 33: 287-297.

Lamprea, M.R, Cardenas, F.P., Vianna, D.M., Castilho, V.M., Cruz-Morales, S.E., Brandão, M.L. (2002) The distribution of fos immunoreactivity in rat brain following freezing and escape responses elicited by electrical stimulation of the inferior colliculus. Brain research, 950 (1-2): 186-94.

Lehner, M., Taracha, E., Skorzewska, A., Wislowska, A., Zienowicz, M., Maciejak, P., Szyndler, J., Bidzinski, A. e Plaznik, A. (2004) Sensitivity to pain and Fos expression in brain structures in rats. Neuroscience Letter, 370(1):74-9.

Linke, R. (1999) Differential projection patterns of superior and inferior collicular neurons onto posterior paralaminar nuclei of the thalamus surrounding the medial geniculate body in the rat. European Journal of Neuroscience, 11(1):187-203.

Linke, R., Braune, G., Schwegler, H. (2000) Differential projection of the posterior paralaminar thalamic nuclei to the amygdaloid complex in the rat. Experimental Brain Research, 138(1):135-8.

Lister, R. G. (1990). Ethological-based animal models of anxiety disorders. Pharmacological Therapy, 46: 321-340.

Lu, B., Lund, R.D. e Coffey, P.J. (2001) Basal increase in c-Fos-like expression in superior colliculus of Royal College of Surgeons dystrophic rats can be abolished by intraocular injection of tetrodotoxin. Neuroscience, 107:109-115.

Martinez, J. C., Cardenas, F., Lamprea, M. e Morato, S. (2002). The role of vision and proprioception in the aversion of rats to the open arms of an elevated plus-maze. Behavioral Processes, 60: 15-26.

McGinty, D., Gong, H., Suntsova, N., Alam, M.N., Methippara, M., Guzman-Marin, R. e Szymusiak, R. (2004) Sleep-promoting functions of the hypothalamic median preoptic nucleus: inhibition of arousal systems. Archives Italiennes de Biologie, 142(4):501-9.

McNaughton, N. e Corr, P.J. (2004) A two-dimensional neuropsychology of defense: fear/anxiety and defensive distance. Neuroscience and Biobehavioral Reviews. 28(3):285-305.

Menard, J. e Treit, D. (1999) Effects of centrally administered anxiolytic compounds in animal models of anxiety. Neuroscience and Biobehavioral Reviews, 23: 591-613.

Mennella, J.A. e Beauchamp, G.K. (2002). Flavor experiences during formula feeding are related to preferences during childhood. Early Human Development 68: 71-82.

Montgomery, K. C. e Monkman, J. A. (1955). The relation between fear and exploratory behavior. Journal of Comparative and Physiological Psychology, 48: 132-136.

Morato, S. e Castrechini, P. (1989). Effects of floor and environmental illumination on exploratory activity in the elevated plus-maze. Brazilian Journal of Medical and Biological Research, 22: 707-710.

Morgan, J. I. e Curran, T. (1991). Stimulus-transcription coupling in the nervous system: Involvement of the inducible proto-oncogenes fos and jun. Annual Review of Neuroscience, 14: 421-45.

Morin, L.P. e Allen, C. N. (2005) The circadian visual system. Brain Research Reviews. Artigo em prensa.

Mrosovsky, N. (1999a) Masking: history, definitions, and measurement. Chronobiology international, 16: 415-429. 
Mrosovsky, N., Foster, R.G. e Salmon, P.A. ( 1999b) Thresholds for masking responses to light in three strains of retinally degenerate mice. Journal of Comparative Physiology. 184: 423-428.

Muscat, L. e Morin L.P. (2006) Intergeniculate leaflet: Contributions to photic and non-photic responsiveness of the hamster circadian system. Neuroscience, 140(1):305-20.

Nasello, A. G., Machado, C., Bastos., J. F. e Felício, L. F. (1998). Sudden darkness induces a high activity-low anxiety state in male and female rats. Physiology and Behavior, 63(3): 451-454.

Nasello, A.G., Sassatani, A.S., Ferreira, F.S., Felício, L.F. e Tieppo, C.A. (2003) Modulation by sudden darkness of apomorphine-induced behavioral responses. Physiology and Behavior, 78(4-5):521-8.

Otake, K., Kin, K. e Nakamura, Y. (2002) Fos expression in afferents to the rat midline thalamus following immobilization stress. Neuroscience Research, 43(3):269-82.

Panda, S., Provencio, I., Tu, D.C., Pires, S.S., Rollag, M.D., Castrucci, A.M., Pletcher, M.T., Sato, T.K., Wiltshire, T., Andahazy, M., Kay, S.A., Van Gelder, R.N.e Hogenesch, J.B. (2003) Melanopsin is required for non-image-forming photic responses in blind mice. Science 301: 525-7.

Papa, M., Pellicano, M.P., H., Welzl, H., Sadile, A.G. (1993) Distributed changes in c-Fos and c-Jun immunoreactivity in the rat brain associated with arousal and habituation to novelty, Brain research bulletin. 32: 509-515.

Paxinos, G. e Watson C. (1997) The Rat Brain.in Stereotaxic Coordinates, Academic Press, New York

Pellow, S. (1986) Anxiolytic and anxiogenic drug effects in a novel test of anxiety: are exploratory models of anxiety in rodents valid?. Methods and findings in experimental and clinical pharmacology, 8:557-565.

Pellow, S. e File, S.E. (1986). Anxiolytic and anxiogenic drug effects on exploratory activity in elevated plus-maze: a novel test of anxiety in the rat. Pharmacology, Biochemistry and Behavior, 24: 525-529.

Pellow, S., Chopin, P., File, S. E. e Briley, M. (1985). Validation of open: closed arm entries in an elevated plus-maze as a measure of anxiety in the rat. Journal of Neuroscience Methods, 14: 149-167.

Pitkanen, A., Jolkkonen, E. e Kemppainen, S. (2000) Anatomic heterogeneity of the rat amygdaloid complex. Folia morphologica. (Warsz), 59(1):1-23.

Prichard, J. R., Stoffel, R. T., Quimby, D. L., Obermeyer, W. H., Benca, R. M. e Behan, M. (2002). Fos immunoreactivity in rat subcortical visual shell in response to illuminance changes. Neuroscience, 114 (3): 781-793.

Pudovkina, O.L., Kawahara Y, de Vries J, Westerink, B.H. (2001).; The release of noradrenaline in the locus coeruleus and prefrontal cortex studied with dual-probe microdialysis. Brain Research. 6 (1-2):38-45

Rasia-Filho, A.A, Londero, R.G e Achaval, M. (2000) Functional activities of the amygdala: an overview. Journal of psychiatry and neuroscience, 25(1):14-23.

Redlin, U. (2001) Neural basis and biological function of mascaragem by light in mammals: suppression of melatonin and locomotor activity. Chronobiology international, 18(5): 737-785.

Redlin, U. e Mrosvsky, N. (1999) masking of locomotor avtivity in hamsters. Journal of Comparative Physiology, 184: 428-437.

Rodgers R.J. e Johnson, N.J. (1995) Factor analysis of spatiotemporal and ethological measures in the murine elevated plus-maze test of anxiety. Pharmacology, biochemistry, and behavior. 52(2):297-303.

Rodgers, R. J. e Cole, J. C. (1994). The elevated plus-maze: Pharmacology, methodology and ethology. Em Cooper S. J e Hendrie, C. A. (Org), Ethology and Psychopharmacology. John Wiley and Sons Ltd., Nova York: 9-43.

Sagar, S. M., Sharp, F. R. e Curran, T. (1988) Expression of Fos protein in brain: metabolic mapping at the cellular level. Science; 240: 1328-1331.

Salomé, N., Salchner, P., Viltart, O., Sequeira, H., Wigger, A., Landgraf, R. e Singewald, N. (2004). Neurobiological correlates of high (HAB) versus low anxiety-related behavior 
(LAB): differential Fos expression in HAB and LAB rats. Biological Psychiatry, 55: $715-723$.

Sara, S.J., Vankov, A. e Herve, A. (1994) Locus coeruleus-evoked responses in behaving rats: a clue to the role of noradrenaline in memory. Brain Research Bulletin. 35(5-6):457-65.

Schmitt, U.e Hiemke C. (1998) Strain differences in open-field and elevated plus-maze behavior of rats without and with pretest handling. Pharmacology, biochemistry and behavior. 59: 807-811.

Schwabe, K, Ebert, U e Loscher, W. (2004) The central piriform cortex: anatomical connections and anticonvulsant effect of GABA elevation in the kindling model. Neuroscience, 126(3):727-41.

Sheng, M. e Greenberg, M.B. (1990) The regulation and function of Fos and other immediate early genes in the nervous system. Neuron, 4(4):477-85.

Silveira, M. C., Sandner, G. e Graeff, F. G. (1993). Induction of Fos immunoreactivity in the brain by exposure to the elevated plus-maze. Behavioral Brain Research, 56:115-118.

Singewald, N. e Sharp, T. (2000). Neuroanatomical targets of anxiogenic drugs in the hindbrain as revealed by Fos immunocytochemistry. Neuroscience, 98: 759-770.

Singewald, N., Salchner, P. e Sharp, T. (2003). Induction of Fos expression in specific areas of the fear circuitry in rat forebrain by anxiogenic drugs. Biological Psychiatry, 53: 275283.

Slavetna, O.V., Khodorovskyi, G.I. (1994) Effect of light condition on the hypothalamohypophyseal-ovary system in young female rats after distraction of the lateral septal nucleus. Fiziologicheski zhurnal, 40(2):10-5.

Smale, L., Lee, T., Nunez, A.A. (2003) Mammalian diurnality: some facts and gaps. Journal of biological rhythms 18(5):356-66.

Stone E.A, Mohammed, L.Y., Ahsan, R., Michael, R., Lehmann, L., Yeretsian, J. e Quartermain, D. (2006) Role of CNS a1-Adrenoceptor Activity in Central fos Responses to Novelty. Synapse, 59:299-307.

Struthers, W.M., DuPriest, A., Runyan, J. (2005) Habituation reduces novelty-induced FOS expression in the striatum and cingulate cortex. Experimental Brain Research, 167(1):136-40.

Treit D. e Menard, J. (2000) The septum and anxiety. Em: Numan, R. Editor, The Behavioral Neuroscience of the Septal Region, Springer, New York, pp. 210-233.

Vrang, N. Mrosovsky, N. e Mikkelsen, J.D. (2003) Afferent projections to the hamster intergeniculate leaflet demonstrated by retrograde and anterograde tracing. Brain Research Bulletin, 59:267-288.

Wang, S.H., Ostlund, S.B., Nader, K e Balleine, B.W. (2005) Consolidation and reconsolidation of incentive learning in the amygdala. The Journal of neuroscience, 25(4):830-5.

Wilson, D.A., e Stevenson, R.J. (2003) The fundamental role of memory in olfactory perception. Trends in Neurosciences. 26(5):243-247.

Windle, R.,J, Kershaw, Y.M., Shanks N., Wood, S.A., Lightman, S.L.e Ingram, C.D. (2004) Oxytocin attenuates stress-induced Fos mRNA expression in specific forebrain regions associated with modulation of hypothalamo-pituitary-adrenal activity. The Journal of Neuroscience, 24(12):2974-82.

Xu, Z., Torday, J., Yao, J..(2003).Functional and anatomic relationship between cholinergic neurons in the median preoptic nucleus and the supraoptic cells. Brain Research. 964(2):171-8.

Zamorskyi, I.I e Khodorovskyi, G.I. (1993) Effect of lateral septal nucleus damage on the photoperiodic changes in the reproductive system of male rats. Fiziologicheski zhurnal, 39(2-3):3-7.

Zhu, X.O., Brown, M.W., McCabe, B.J. e Aggleton, J.P. (1995) Effects of the novelty or familiarity of visual stimuli on the expression of the immediate early gene c-fos in rat brain. Neuroscience, 69(3):821-9. 


\section{Anexos}

\section{Labirinto em cruz elevado \\ Claro \\ Amígdala central

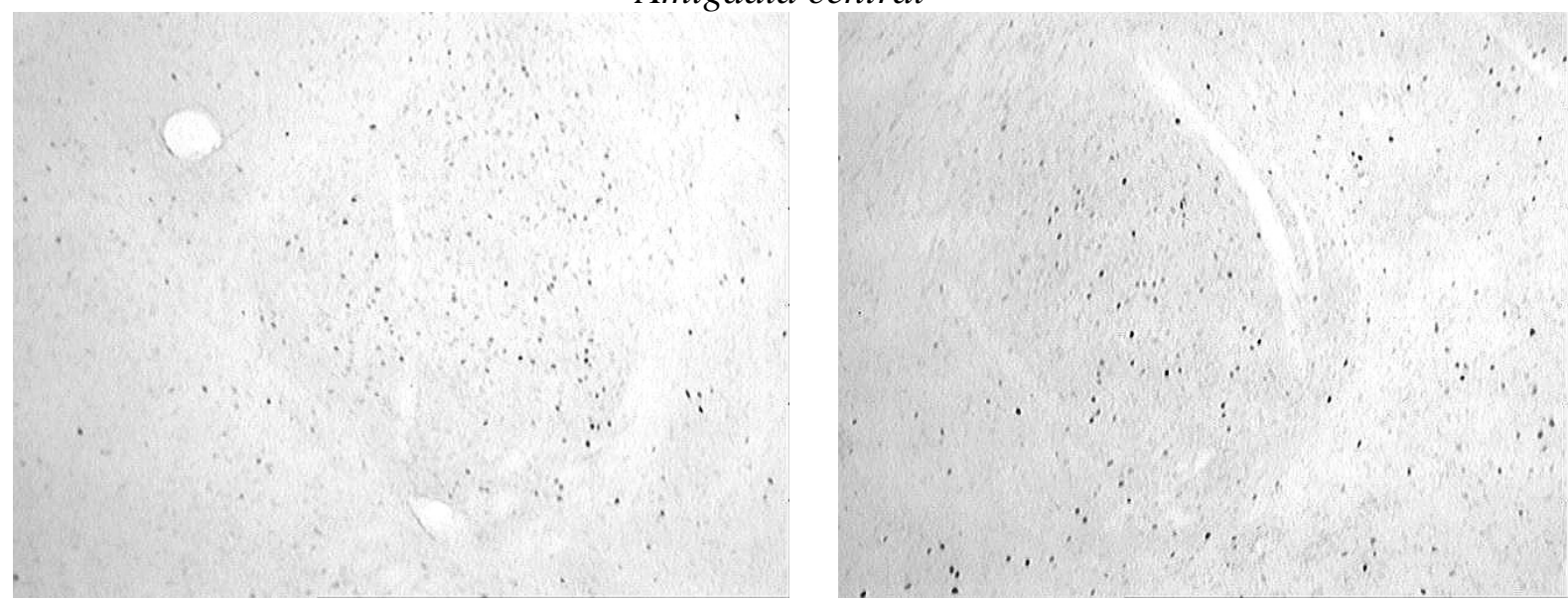

Amígdala basolateral

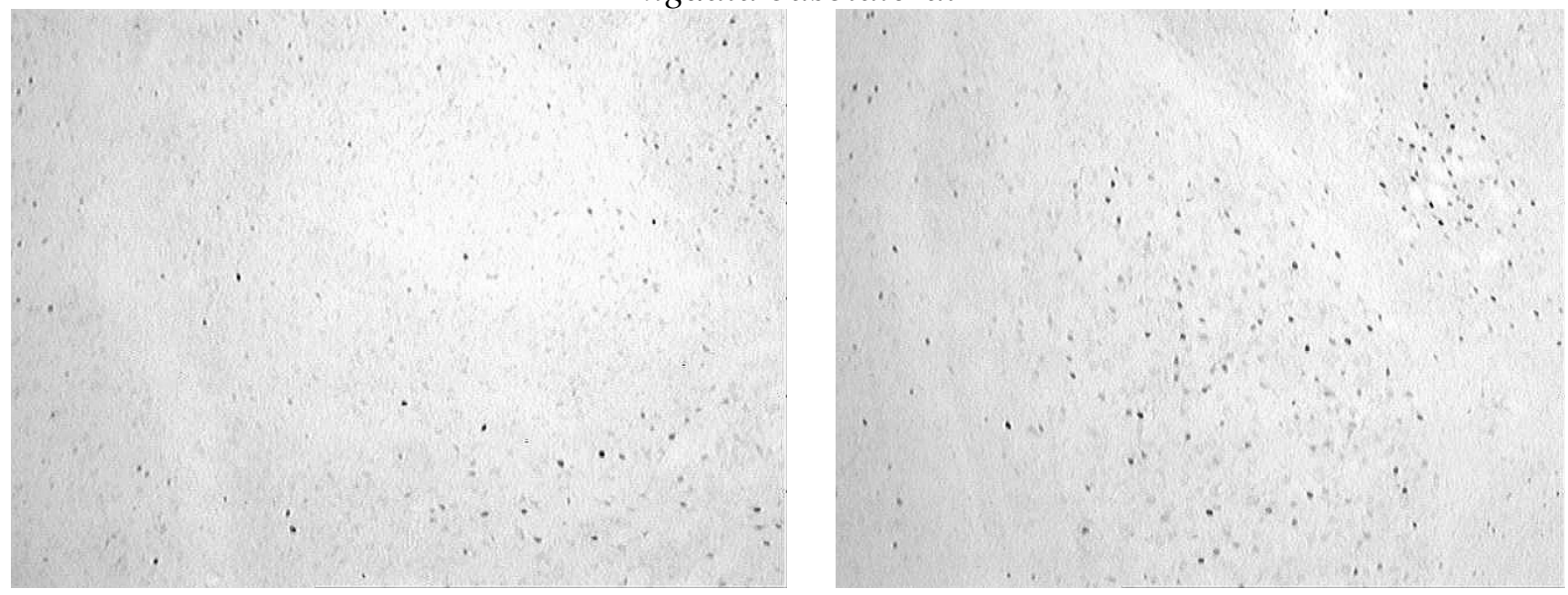

Amígdala medial

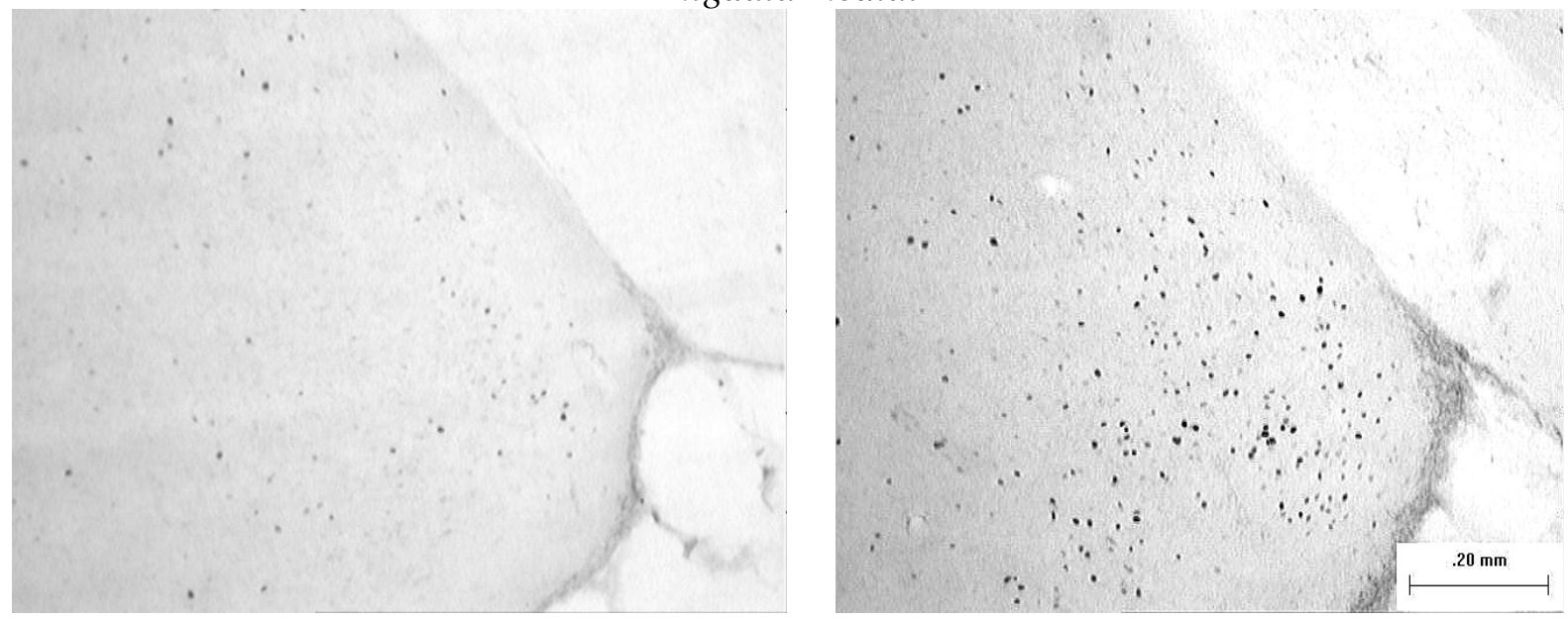

Figura 12. Fotomicrografias de cortes coronais da amígdala mostrando a distribuição de Fos após o teste no labirinto em cruz elevado no claro e no escuro. Barra $=0,20 \mathrm{~mm}$ 
Claro

Escuro

Córtex piriforme

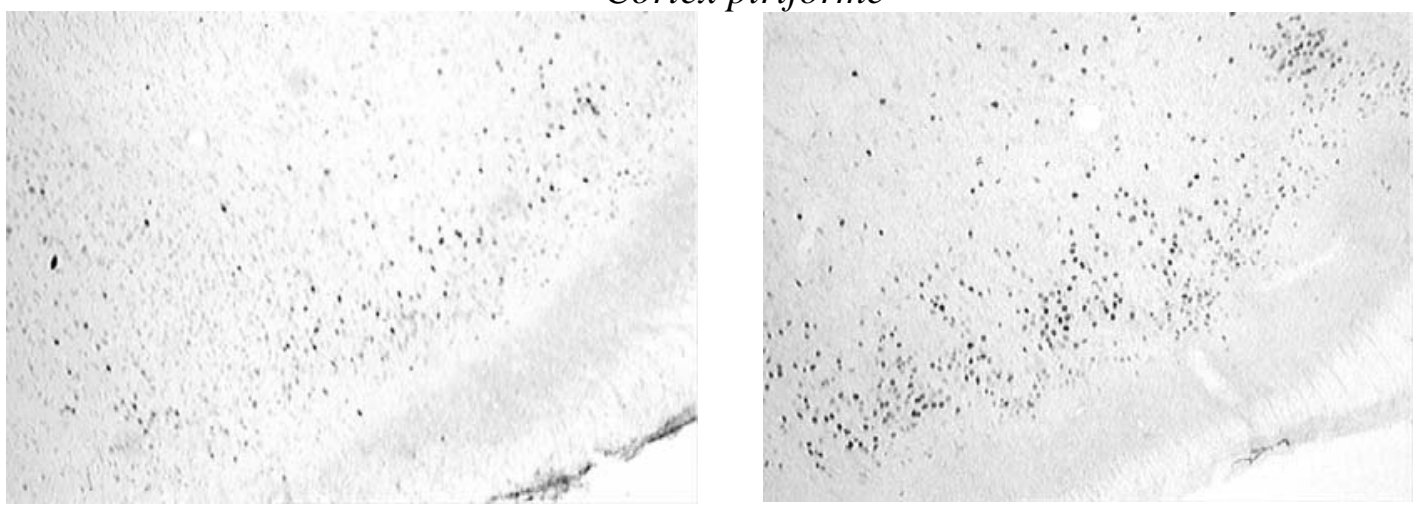

\section{Hipotálamo dorsomedial}
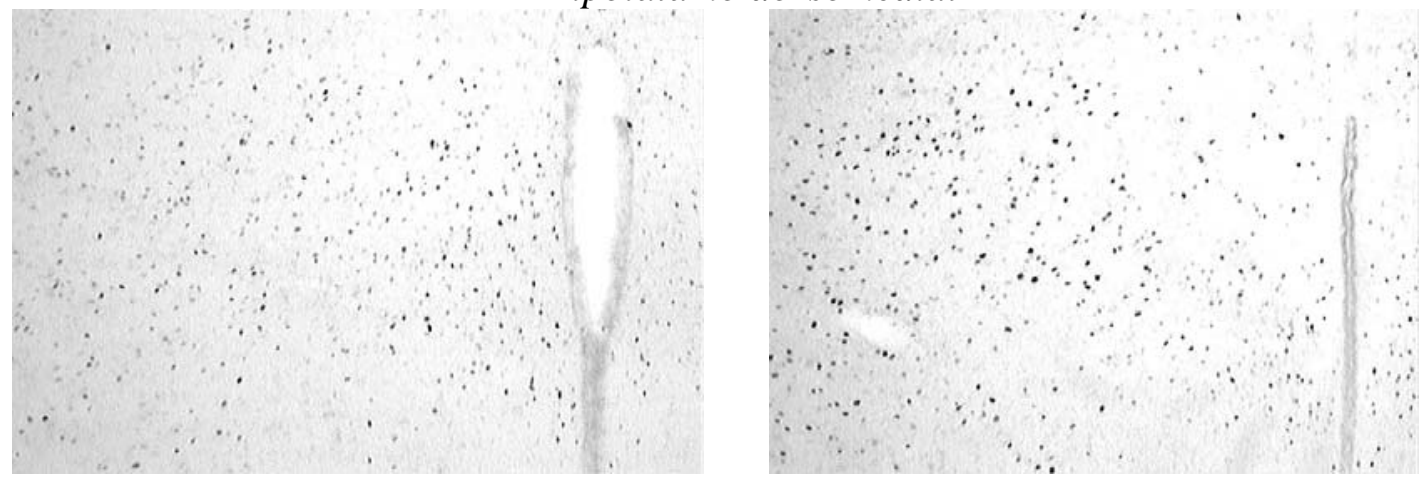

\section{Lâmina intergeniculada}

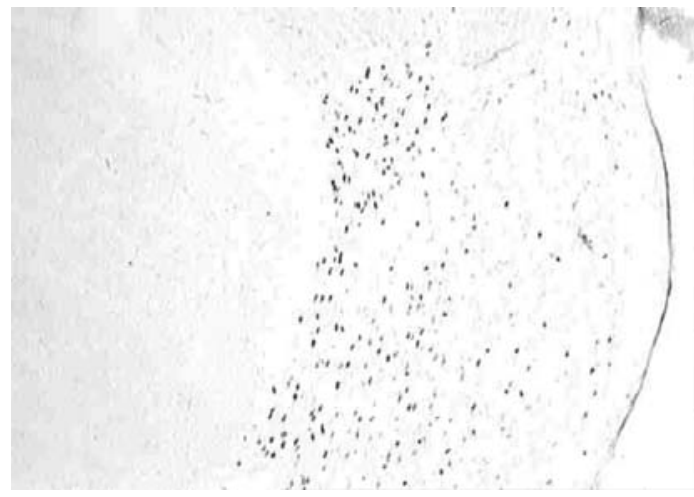

Locus coeruleus
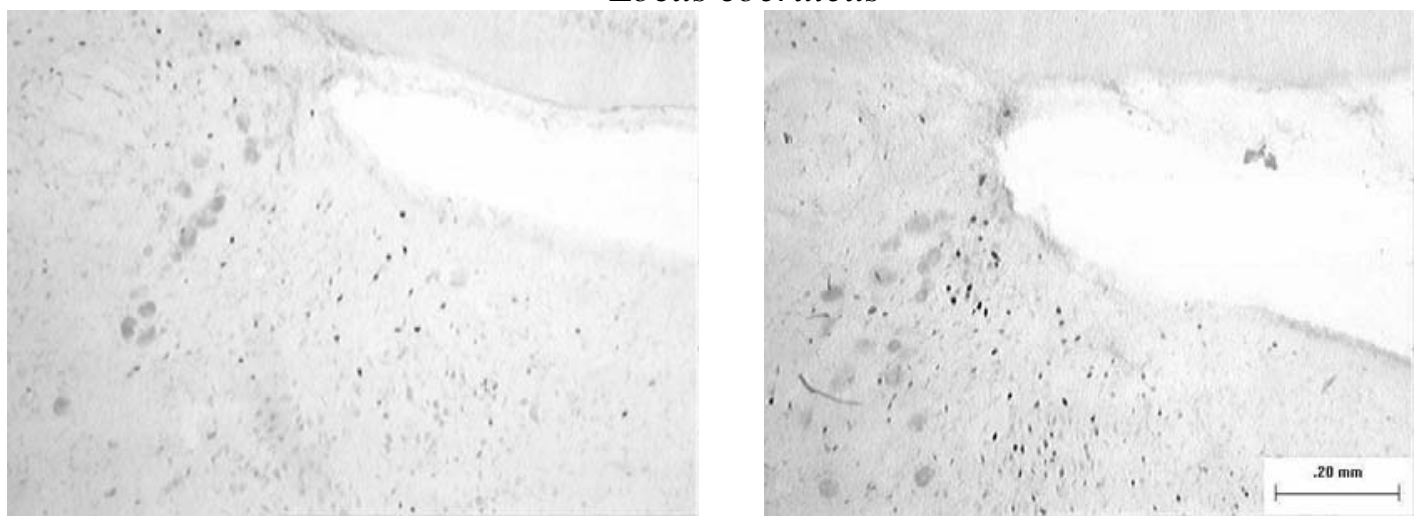

Figura 13. Fotomicrografias de cortes coronais de diferentes estruturas mostrando a distribuição de Fos após o teste no labirinto em cruz elevado no claro e no escuro. Barra $=0,20 \mathrm{~mm}$ 